\title{
The I, the T or the Q? Which fishing opportunity attributes are associated with sustainable fishing?
}

Maartje Oostdijk ( $\nabla$ maartje.oostdijk@gmail.com )

University of Iceland

Griffin Carpenter

New Economics Foundation

\section{Article}

Keywords: sustainable fishing, individual transferable quotas (ITQs), management systems

Posted Date: September 28th, 2020

DOI: https://doi.org/10.21203/rs.3.rs-74387/v1

License: (9) This work is licensed under a Creative Commons Attribution 4.0 International License.

Read Full License 
1 Title: The I, the $\mathbf{T}$ or the $\mathbf{Q}$ ? Which fishing opportunity attributes are associated with

$2 \quad$ sustainable fishing?

3 Authors: Maartje Oostdijk, ${ }^{1,2}$ Griffin Carpenter ${ }^{3}$

4 Affiliations:

1. Department of Life and Environmental Sciences, University of Iceland, Sturlugötu 7, 101 Reykjavík, Iceland

2. Department of Physical Geography, Environment and Resource Dynamics Group, Stockholm University, 11419 Stockholm, Sweden

3. New Economics Foundation, 10 Salamanca Place, London SE1 7HB

\section{Abstract}

12 While several prominent studies link the use of individual transferable quotas (ITQs) to 13 sustainable fishing, it remains unclear which attributes of this system (i.e., individual, 14 transferable, or quota), or any other system, lead to sustainable outcomes. To test for a linkage 15 between management systems and sustainable fishing, we systematically classified how fishing opportunities are allocated for 443 fish stocks from 1990 to 2018 to produce the largest database of its kind. Using mixed-effects models and a difference-in-differences approach, we tested the occurrence of system attributes against two metrics of sustainable fishing: mortality 19 (i.e., overfishing) and biomass (i.e., overfished). Our results reveal that quota limits and 20 individual allocation reduce the probability of overfishing, but offer no evidence supporting 21 the transferability of fishing opportunities or the length of time they are held for. These results highlight the importance of considering specific attributes in the design of fisheries management systems. 


\section{Introduction}

27 Individual transferable quotas (ITQs), where harvest limits are held individually, for a long 28 duration, and can be freely transferred, are an increasingly used fisheries management system throughout global fisheries ${ }^{1,2}$. While several prominent studies have linked the use of ITQs to sustainable fishing ${ }^{3,4}$, the effect of each ITQ attribute (i.e. the I, the T, and the Q), remains

31 underexplored and the lessons for policy design unclear ${ }^{5}$.

32 For each ITQ attribute, theoretical claims have been made supporting a link to sustainable 33 fishing, but counterclaims have also been raised. Limiting catches through quota has the 34 advantage over limiting fishing effort (e.g. time at sea, number of hooks or pots) that it is more closely tied to fishing mortality ${ }^{6,7}$ and more predicable to control $^{8,9}$, although quota limits may be more difficult to enforce and over-quota catches simply discarded at sea ${ }^{10,11}$. Allocating

37 fishing opportunities to individuals empowers fishers to choose when to use them ${ }^{12}$, including 38 during lower impact fishing seasons, however the common-pool aspect of fish stocks and thus the incentive for individuals to fish more remains ${ }^{10}$. Transferability in fishing opportunities will lead to concentration in the hands of the most profitable businesses ${ }^{6,13}$ who may be more likely to pay for management ${ }^{14}$ of a smaller fleet ${ }^{15}$, but profitability is not synonymous with efficiency given unaccounted for externalities ${ }^{7,16}$, and transferability of fishing opportunities and fleet contraction can still occur through vessel sale if quota trade is prohibited.

44 Beyond these ITQ attributes, there is little literature on the attributes used in alternative allocation systems, such as pooling (i.e. opportunities are fished collectively without allocation to individuals), leasing, rationing throughout the year, and leaving the industry to self-govern

47 (e.g. the allocation of fishing opportunities to a cooperative, not including initial individual 48 allocation that is later grouped by cooperatives ${ }^{17}$ ). While we explore these other attributes and 
49 their link to fisheries sustainability in this article, we mainly focus on the I, T, Q attributes as this is the domain where theories have been advanced.

51 The allocation of fishing opportunities is closely linked to duration, and several studies have claimed that when the duration of exclusive fishing opportunities is sufficiently long and secure, the long-term sustainability of the fish populations is in the interest of fishers themselves as they will bear the consequences of (un)sustainable behaviour ${ }^{18,19}$. This is disputed, however, as other studies have noted that the common-pool aspect of fish stocks and the incentive to overfish remains, hence the need for enforcement ${ }^{5}$, and long-term property rights in other sectors have still led to unsustainable behaviour ${ }^{5}$.

As many of the theoretical claims linking ITQ attributes to sustainable fishing are contested, it is especially important to test the empirical effect of existing fisheries management systems. Unfortunately, much of the existing empirical literature does not distinguish between the different attributes of management systems (Table 1) and some studies have used contested proxies as metrics of sustainable fishing ${ }^{20}$. By ignoring attributes, the control groups used in these studies also suffer as all other management systems, including systems with no management at all, are grouped together. The few empirical studies that analyse system attributes show no conclusive evidence that individual allocation, transferability, or duration are associated with sustainable fishing beyond the benefits of quota management (Table 1).

As there are conflicting theoretical claims and as the empirical evidence on specific attributes is limited and ambiguous, an important research question remains: Which attributes of fisheries management systems, if any, are associated with sustainable fishing? For this purpose, we compiled the largest dataset on fisheries management systems to date, covering 1990-2018, and tested different systems and their attributes against two metrics of sustainable fishing: 
mortality (i.e., whether a fish stock is subjected to overfishing) and biomass (i.e., whether a fish stock is overfished).

\section{Results}

\section{Fisheries management systems}

The most frequently observed fisheries management system in our dataset was total effort (TE, number of stocks $=174$, Figure $1 \mathrm{~A})$, where an input to fishing is managed at the fleet level. The second most observed management system was individual transferable quota (ITQ, $n=151$ ) followed closely by total quota pool (TQP, $n=112$ ), where a quota cap is set and fished collectively by the fleet until it is exhausted. Individually rationed quota pool (IRQP, a collective quota system where quota is allocated in rationed periods over the year, e.g. a weekly limit for vessels) and individual quota (IQ) were also frequently observed ( $n=63$ and $n=46$, respectively, Figure 1A). Other allocation systems were extremely rare: rationed individual quota (RIQ, $\mathrm{n}=4$, where individual quota is allocated for a shorter term than a full season), self-governed quota pool (SGQP, $n=4$, where quota is formally allocated to a group such as a cooperative), individual transferable effort (ITE, $n=3$ ) and rationed quota pool $(\mathrm{RQP}=, \mathrm{n}=2$, where quota is allocated to the fleet, for a shorter time than one fishing season).

[Figure 1]

91

Regarding the duration for which individual quota (IQ, ILQ, ITQ) are held, most individual quota was held with a 'legal ability' to change allocations (e.g. by changes in the fisheries management plan, $n=77$, Figure $1 \mathrm{~B}$ ). Other durations were all also frequently observed

95 (indefinite, $n=40$, multiple seasons, $n=35$ and for one single season, $n=31$, Figure $1 B$ ).

\section{Sustainable fishing indicators}


97 We found that overfishing frequently occurred in all management systems and regions. The regions with the highest shares of overfishing were the Mediterranean \& Black Sea region and northern Europe with 84 percent and 69 percent of observations, respectively. TE, unregulated,

100 RQP, RIQ, and ITE management regimes had the largest shares of overfishing occurring, 101 ranging between 71 and 100 percent of observations. In contrast, TQP, IRQP, ITQ, and individual leasable quota (ILQ) management regimes had the lowest share of overfishing ranging between 30 and 36 percent of observations (Figure 2A).

104

Of the total sample, a smaller amount of fish stocks, only 32 percent, were in an overfished state. Individual effort (IE) was the management regime with the largest share of fish stocks in an overfished state with 71 percent of observations, followed by TE and unregulated with 45 and 44 percent respectively (Figure 2B).

109

\section{Effects of fisheries management systems on sustainable fishing indicators}

111 Several fisheries management systems reduced the probability of overfishing and/or being in

112 an overfished state when compared to the control system of TE (Figure 2C). Strong effects for

113 reducing overfishing were found for individual quota systems (including ITQ, ILQ, and IQ),

114 although the strongest effect was found for SGQP (Figure 2C). TQP, another form of pooled

115 quota, also significantly reduced the probability of overfishing, although the effect was smaller

116 (Figure 2C). ILQ and ITE reduced the probability of overfished biomass (Figure 2C), although

117 there were few of these systems and the confidence intervals are wide.

118 [Figure 2]

119 Disentangling the effects of the $\mathbf{I}$, the $\mathbf{T}$, and the $\mathbf{Q}$ on sustainable fishing 
120 Without controlling for other factors (i.e., region, time, fish stock), systems with the attributes

121 of quota limits, individual allocation, and transferability had lower frequencies of overfishing 122 and overfished states, with the largest difference for quota limits ( 71 percent without versus 40

123 percent with quota limits, Figures $3 \mathrm{~A}$ and $3 \mathrm{~B})$.

124 Association between attributes and sustainable fishing (mixed regression models): Controlling

125 for other factors in the mixed-model analysis, we found a reduced probability for overfishing 126 when fisheries were under quota limits and/or when fishing opportunities were allocated 127 individually (Figure 3C), with the largest effect found for quota limits. We found that the 128 predicted probabilities of overfishing were, on average, 0.5 without quota versus 0.3 with quota.

129 For individual allocation, the probability of overfishing without individual allocations was, on 130 average, 0.45 versus an average probability of 0.25 for a stock with individual allocations 131 (Figure B1). However, considerable uncertainty in the random effects resulted in wide prediction confidence intervals (Figure B1). For transferability, despite a lower occurrence of overfishing (Figure 3A), no significant effect was found when other factors were accounted for

134 in the mixed-model analysis (Figure 3C). None of the attributes had a significant effect for 135 stocks being in an overfished state (Figure 3C). We found no significant difference in the 136 probability of overfishing when systems with longer durations were compared to those 137 allocated for a single season, although there was an increased probability of an overfished state 138 when fishing opportunities were allocated for fixed multiple seasons (Figure 3D).

139 Difference-in-differences: We found a significant reduction in the probability of overfishing 140 for the addition of Q (fisheries transitioning from IE to IQ) and for the addition of I (TE to IE) 141 (Figure 4). Where multiple attributes were jointly added to a system, we found a reduced 142 probability of overfishing and the overfished state where pooled quota fisheries transitioned 143 became individual and transferable (i.e. transitioned to ITQ) but found no significant effect for 
144 TE managed fisheries that became quota, individual, and transferable (i.e. transitioned to ITQ).

145 This finding may be regionally confounded as 18 of the 20 treatment fisheries that transitioned

146 from TE to ITQ were Australian fisheries in the early 1990s. None of the transitions were

147 associated with a change in the probability of stocks being overfished (Figure 4).

148 Refining the DiD approach to 22 paired treatment and control fisheries, where treatment

149 fisheries transitioned from pooled quota to individually allocated quota revealed no significant change in the probability of overfishing or overfished outcomes (Figure 4).

\section{Sensitivity test using mortality and biomass trends}

152 The analysis of the trend indicators showed that IE increased the probability of a declining trend in overfishing (Table B2), while these systems were not associated with reduced overfishing using the sustainability threshold (Figure 2). We found the reverse for ITQ and

155 TQP (i.e. while these systems reduced the probability for overfishing, they reduced the

156 probability of an increasing trend for stocks that were experiencing overfishing). We found no

157 significant change in the probability of an increasing trend in biomass for overfished stocks

158 under any management system (Table B2). We also found no significant change in trends for

159 Q, I, T, or D (Figure B2 and B3). Using the DiD approach, we found a small effect on the 160 increase in the probability of reduced overfishing when fisheries transitioned from TE to IE 161 (the addition of I) (Figure B4).

\section{Sensitivity test using alternative thresholds for overfishing and overfished}

163 Applying alternative sustainability thresholds (high overfishing: $\mathrm{F} / \mathrm{F}_{\mathrm{msy}}>1.5$; highly overfished:

$\left.164 \mathrm{~B} / \mathrm{B}_{\mathrm{msy}}<0.5\right)$ resulted in changes to the significant effects (Table B3). Whereas IRQP, IE, and unregulated fisheries did not have an effect at the original overfishing threshold (Figure 2C), 

these systems were associated with a reduced probability of high overfishing (Table B3). IE systems also has a significant effect on biomass at a highly overfished level (Table B3).

168 At the attribute level, the results were largely unchanged when alternative sustainability 169 thresholds were applied (i.e., a reduced probability of high overfishing with individual 170 allocation and quota limits) and the effect sizes increased (Figure B5). The lack of effect for 171 duration also remained unchanged (Figure B6).

172 The results from the DiD analysis shifted considerably with alternative sustainability thresholds, with several more transitions reducing the probability of high overfishing (Figure B7). Adding Q (IE to individual quota; TE to non-individual quota) and adding I (TE to IE; non-individual quota systems to individual quota) resulted in a reduced probability of high overfishing (Figure B7). Transitioning from non-individual quota to ITQ reduced the probability of a highly overfished state (Figure B7). In contrast, transitioning from TE to IE increased the probability of a highly overfished state occurring (Figure B7).

\section{Discussion}

180 We set out to understand the degree to which fishery management systems, and in particular systems that include I, T, Q, and/or D, affect sustainable fishing. After classifying management systems used in hundreds of fisheries around the world, we found that management systems using quota limits, particularly those allocated individually (IQ, ILQ, ITQ), reduced the probability of overfishing compared to TE management. ILQ and ITE were the only systems associated with a reduction in the probability of stocks being overfished, with considerable uncertainty.

187 Disentangling the effects of I, T, and Q as system attributes, we found that Q and I were associated with large reductions in the probability of overfishing, and that this effect was 
stronger when we applied an alternative threshold for overfishing (i.e., high overfishing, $\mathrm{F} / \mathrm{F}_{\mathrm{msy}}$

$190>1.5)$. These results were only somewhat reflected in biomass indicators; individual allocation

191 increased stock biomass for overfished stocks, but not to a level that prevented the probability

192 of stocks remaining in an overfished state. From these results, we conclude that quota systems

193 tend to outperform effort systems in terms of delivering sustainable fishing, and that individual

194 systems tend to outperform systems with total, pooled limits. The result for individual

195 allocation, however, seems to be largely driven by individual quota systems (I+Q, Figure 2)

196 and is thus not entirely independent (i.e. I acts in interaction with Q).

197 Quota limits may contribute to fisheries sustainability through their direct link to fisheries

198 mortality (i.e., closing a fishery when the quota has been fished), while effort restrictions have

199 a margin of uncertainty in their appropriate levels within the year ${ }^{21}$. Moreover, when effort

200 restrictions are used, fishers can invest in greater efficiencies in catch and mortality per unit of

201 restricted effort (i.e., technological creep or input substitution), which severely complicates the

202 setting of effort limits at sustainable levels ${ }^{8,9}$.

203 The reduced probability of overfishing in individual systems could potentially be caused by the

204 elimination of the race to fish in individual systems ${ }^{12}$, which may result in a more targeted

205 fishery and a reduced need to discard fish ${ }^{14,22,23}$. It may also result in catches that are lower compared to total allowable catches ${ }^{4}$. A longer fishing season may aid enforcement (e.g. in a

207 fishery with a very short season it may be more difficult for coastguards to monitor over-quota

208 catches or illegal discarding) $)^{22}$, as would the accountability of individual allocations as these

209 are held (and exceeded) by a fisher or a company rather than the entire fleet.

210 We found no effect for either the transferability of fishing opportunities or their duration, which

211 suggests that the casual mechanisms underlying our findings for individual allocation may not 
212 be related to secure property rights in fisheries, or the use of market-based systems, as has been

213 suggested in previous literature ${ }^{3,12}$.

214 Costello et al. (2008) ${ }^{3}$ found that 'catch shares' (specifically ITQs) prevented fisheries 215 collapse, defined as landings below 10 percent of historical levels. While the study was the 216 first of its kind, it suffered from several shortcomings. In the study, control fisheries were not 217 classified and the comparison group, all non-ITQ fisheries, included many unregulated 218 fisheries, making it impossible to disentangle the effect of implementing whether a reduced 219 probability of collapse was due to I, T, or Q attributes ${ }^{5}$. In addition, it has been demonstrated 220 that landings data, the proxy used for sustainable fishing, is a poor indicator of stock status ${ }^{20}$. 221 Subsequent studies have nuanced these results. For instance, a subsequent study by the same authors $^{24}$ addressed some of the issues by investigating the impact of ITQs on fisheries that already had quota limits in place, and found that effects were still present, although weaker, than in the earlier study (Table 1). Other, more nuanced studies found mixed results for the sustainability benefits of management systems (Table 1). The few studies that have analysed specific system attributes have consistently found that Q improves sustainable fishing, a weak effect for I, and no consistent effect for either T or D (Table 1). Our findings are similar, as we found a reduced probability of overfishing for fisheries managed by Q and I but not for T or D.

While our study addresses many of the confounding issues in previous literature, several limitations remain. First, we cannot guarantee that our control and treatment fisheries are similar, for example regional circumstances may differ even for adjacent regions ${ }^{25}$, or that

232 fisheries undergoing management change may undergo transitions due to a current or recent 233 fisheries collapse ${ }^{15,26}$. Second, the scope of this study is limited to governmental policy, and 234 thus in our classification method we relied on the legal definitions of fisheries management systems. Systems may differ from what is described on paper or may develop important 
attributes in parallel to the governmental system (e.g. producer organisations and fishing cooperatives may pool fishing opportunities that were initially individually allocated). Similarly, the legal definitions of duration may differ from the perceived duration of fishing opportunities based on historical precedent. However, our result for duration based on legal definitions aligns with ${ }^{27}$ who used perceived duration. Differentiating between systems as defined by policy and systems as they operate in practice is one area for future research and even further nuance in studying fishing opportunities. Third, our approach relies on defined thresholds for overfishing and overfished states and does not allow for comparison with previous work that studied continuous indicators of fish stocks ${ }^{28,29}$. We believe, however, that higher or lower fishing pressure can only be assessed against a defined threshold (i.e., an increase in fishing pressure from a low base could still be sustainable).

Based on our methodology and new dataset of fisheries management systems, we found evidence that both Q and I attributes were associated with a reduced probability of overfishing. The effect of different management attributes on sustainable fishing was not ubiquitous, however, as this finding was only slightly reflected in the probability of a stock being overfished and we found no benefit for stocks already under quota transitioning to individual quota or individual transferable quota when we matched these to control fisheries that continued to use pooled quota. Whereas some previous studies have emphasised that marketbased systems (i.e., the presence of transferability) or those with strong property rights (i.e., a long duration) are associated with sustainable fishing, these benefits disappear with proper controls for other attributes of fisheries management systems. These results highlight the importance of considering specific attributes in the design of fisheries management systems. 


\section{Methods}

\section{Data collection}

262 Management data: To classify fisheries management systems, we used a combined primary

263 and secondary research approach by reviewing government legislation and existing fisheries 264 literature as well as consulting fisheries managers and research specialists. In total, we consulted 230 experts for classification queries; 173 replied; of which 116 either provided or confirmed classifications. The resulting dataset is stored online with open access for further verification and use (fishing-opportunities-database: https://docs.google.com/spreadsheets/d/1UaKeXxEfVYCp5xzZwOHAnIRf1UzE484G9k1Y $\underline{\text { L4SaynM/edit). }}$

Biological data: For data on our sustainability metrics we used the RAM legacy database v4.491 (https://www.ramlegacy.org/, RAM Legacy Stock Assessment Database (2018)). These data were extracted from stock assessment documents with information on estimated annual biomass (spawning stock biomass or total stock, we refer to both of these measures as B) and exploitation rates (instantaneous fixing mortality or exploitation ratios (catch/total biomass), we refer to both of these measures as F). We only used assessments which also estimated target reference points that would generate maximum sustainable yield (i.e. $\mathrm{F}_{\mathrm{msy}}$ and/or $\mathrm{B}_{\mathrm{msy}}$ ). Stocks were only included if they had five years of data on $\mathrm{F} / \mathrm{F}_{\mathrm{msy}}$ and/or $\mathrm{B} / \mathrm{B}_{\mathrm{msy}}$ from 1990 to 2018 .

\section{Management systems classifications}

280 We developed 12 exhaustive classifications of management regimes based on a decision tree of potential attributes (Figure 1). Classifying management systems based on attributes in a decision tree allowed for the standardisation of systems where existing definitions were vague and allowed us to control for system attributes in a straightforward manner. Each branch in the 
decision tree (Figure 1) indicated the presence or absence of a system attribute (e.g. the first branch indicated whether quota or effort management was used). The blue-shaded boxes in Figure 1 are the 12 exhaustive classifications used in this study.

287 Where multiple allocation systems were used by a fisheries administration to manage a fish stock (e.g. different systems for coastal and industrial fleets), we assigned a percentage to each system based on the size of the allocation to each subsystem. Similarly, where multiple fisheries administrations exploited the same fish stock, we assigned a percentage to each

291 fisheries administration based on the size of the allocation to each fishing administration, or, if no formal shares existed, the size of catches. The resulting stock classifications were thus a combination of systems used between administrations (where applicable) and within

294 administrations (where applicable). If the use of multiple management systems prevented any one system from representing 75 percent of the fishing pressure for a fish stock, then we did not assign a classification to that fish stock as it was a 'mixed system' (following ${ }^{4}$ ). Particular system attributes (e.g. quota, individual) could reach the 75 percent threshold if they were present in multiple systems leading to the inclusion of these stocks in the attribute-level analysis.

300 In addition to the method for allocating fishing opportunities, we also classified the duration

301 of fishing opportunities into four categories: single season, fixed multiple seasons, indefinite, or of an unspecified duration with the legal ability to change allocations (Figure 1B, further details in Appendix A). Individual allocation and duration are often used as interchangeable

304 terms (e.g. analysis of 'catch shares'); however, duration operates as an independent attribute that can vary across all allocation types, as confirmed by the resulting classifications (fishing-

opportunities-database). We only assessed duration for individual systems, where fishing 
opportunities were allocated as a separate unit from the fishing licence which may have had its own specified duration.

\section{Sustainability definitions}

310 To define sustainable fishing, we assessed fish stocks against two metrics (in line with ${ }^{4,29}$ ):

311 fishing mortality divided by the fishing mortality needed to achieve maximum sustainable yield

$312\left(\mathrm{~F} / \mathrm{F}_{\mathrm{msy}}\right)$, and biomass divided by the biomass that can produce maximum sustainable yield

$313\left(\mathrm{~B} / \mathrm{B}_{\mathrm{msy}}\right)$. We defined a fish stock as subjected to overfishing when the fishing mortality was

314 higher than 1.1 times $\mathrm{F}_{\text {msy }}$ (following ${ }^{4}$ ) and a fish stock as overfished when the stock biomass

315 was lower than $0.8 \mathrm{~B} / \mathrm{B}_{\text {msy }}$ (following ${ }^{30}$ ). We only included stocks from the year that $\mathrm{F} / \mathrm{F}_{\mathrm{msy}}$

316 was at least 0.5 (where data on $\mathrm{F} / \mathrm{F}_{\text {msy }}$ was available) to control for fisheries that were not yet

317 developed or of little commercial interest.

318 Sensitivity analyses: Due to a potential delay between management change and sustainable

319 fishing ${ }^{15}$, we included trend indicators for mortality and biomass to assess whether stocks that 320 did not meet sustainable fishing metrics were trending toward the threshold. When a stock was 321 experiencing overfishing (i.e., $\mathrm{F} / \mathrm{F}_{\mathrm{msy}}>1.1$ ), but the level of $\mathrm{F} / \mathrm{F}_{\mathrm{msy}}$ was lower compared to the 322 average of the previous three years, the observation was recorded as decreasing mortality.

323 When a stock was overfished (i.e., $\mathrm{B} / \mathrm{B}_{\mathrm{msy}}<0.8$ ), but the level of $\mathrm{B} / \mathrm{B}_{\mathrm{msy}}$ was higher compared 324 to the average of the previous three years, the observation was recorded as increasing biomass.

325 As a second sensitivity analysis, we used two alternative thresholds for the definition of 326 overfishing and overfished (both also used in $\left.{ }^{4}\right)$, for high overfishing $\left(\mathrm{F} / \mathrm{F}_{\mathrm{msy}}>1.5\right)$ and highly 327 overfished $\left(\mathrm{B} / \mathrm{B}_{\mathrm{msy}}<0.5\right)$.

\section{Data analyses}


329 To estimate the effect of management systems and their attributes on fisheries sustainability

330 we used two modelling approaches: (1) a set of mixed-effects regressions testing both systems

331 and attributes, and how these were associated to fisheries status; and (2) a difference-in-

332 differences (DiD) approach that tested systems where attributes changed (also using mixed

333 effects).

334 The mixed-effects modelling framework allowed for the introduction of random effects for 335 variables where the sustainability indicators were more likely to share a similar response. For 336 example, a response of a stock in one region to a management system was more likely to 337 correlate to the response of another stock in the same region ${ }^{31}$.

338 First, we modelled the sustainable fishing metrics $S$ for region $r$, stock s, and year $t$ as a function 339 of the fisheries management system (and its multiple attributes):

$S_{r, s, t}=\beta_{1} M_{r, s, t}+R_{r}+R_{s}+\varepsilon_{r, s, t}$

341 where $M_{r, s, t}$ is a dummy variable for the management system in place, $R_{r}$ is a random effect

342 dummy variable for the region, $R_{S}$ is a dummy variable for the stock-specific random effect,

343 and $\varepsilon_{r, s, t}$ is the error term. We compared the effects of all management systems against total

344 effort (TE) as a control group as there are very few unregulated fisheries in our dataset.

345 Second, we modelled the sustainable fishing metrics as a function of the attributes I, T, and/or 346 Q reflecting the theoretical literature (Table 1):

$S_{r, s, t}=\beta_{1} Q_{r, s, t}+\beta_{2} I_{r, s, t}+\beta_{3} T_{r, s, t}+R_{r}+R_{s}+\varepsilon_{r, s, t}$

348 The metrics of sustainable fishing was modelled by dummy variables Q (quota), I (individual) and T (transferable). Random effects were the same as in Equation (1). 
351 We modelled the impact of the duration of fishing opportunities as follows:

352

$S_{r, s, t}=\beta_{1} D_{r, s, t}+R_{r}+R_{s}+\varepsilon_{r, s, t}$

353

where $D_{r, s, t}$ represents the duration of fishing opportunities in a management system. We compared the effects of duration against single season as a control group. Random effects were the same as for Equations (1) and (2).

As a second approach, we employed a DiD analysis for all transitions where a Q, I, or T element was "added", for instance a transition from non-individual effort management to individual effort management (addition of I), or a transition from individual quota to ITQ (addition of T). We also employed DiD for transitions where multiple elements were added, i.e., a transition from non-individual effort to ITQs (addition of Q, I, and T). This second approach is commonly used for analysing time series data where systems that undergo a change (i.e., treatment) are compared to systems that remain the same (i.e., control). A key assumption in this approach is that treatment stocks would have followed a similar trajectory to control fisheries if no change had occurred ${ }^{32}$. DiD modelling was previously employed to study the effects of IQs, ILQs, and ITQs on sustainable fishing (Table 2).

366 Equation 4 represents the DiD approach where treatment stocks were compared to control 367 stocks:

$S_{r, s, t}=\beta_{1} T r_{r, s, t}+R_{r}+R_{s}+\varepsilon_{r, s, t}$

369 The sustainable fishing metrics were modelled by dummy variable $\operatorname{Tr}$ (treatment, i.e., addition 370 on I, T, or Q in the treatment fishery, a dummy variable which was coded 1 after the addition 371 of the attribute and coded 0 for control stocks or prior to introduction of the attribute in treatment fisheries). The other variables are the same as Equations (1)-(3). 
373 For a subset of stocks $(n=22)$, we matched treatment and control stocks for the same species in

374 the same region or regions closely located to one another (Table A2). This approach controlled

375 for confounding circumstances, such as changes in demand or climate change impacts that

376 affected particular species and regions ${ }^{32}$. Treatment fisheries transitioned from pooled quota to

377 individual allocation while control fisheries remained under pooled quota. Previous research

378 requested such an approach be undertaken to separate the effects of attributes of I(T)Q systems

379 from the effects of quota management (Branch, 2009; Bromley, 2009). For this analysis, we

380 grouped all individually allocated quota systems due to the small sample size. For this approach

381 we included a random effect for each treatment and control pair:

382

$S_{r, s, t}=\beta_{1} T r_{r, s, t}+\beta_{2} P_{r, s, t}+\beta_{3} T r_{r, s, t} * P_{r, s, t}+R_{c}+R_{s}+\varepsilon_{r, c, s, t}$

383 The sustainable fishing metrics $S$ were modelled by dummy variable $\operatorname{Tr}$ (treatment), $P$ (before

384 and after treatment) and their interaction, $\beta_{3}$ represents the $\mathrm{DiD}$ estimator ${ }^{32} . R_{c}$ is a dummy

385 variable for the treatment and control pair; the rest of the random effects were the same as in

386 the other equations.

387

388 For each model, we assumed that the residuals followed a first order autocorrelated process

389 which controlled for the fact that the time-series observations were serially correlated at the

390 stock-level. All models were implemented using the package GlmmTMB ${ }^{33}$ in R studio version

$391 \quad 1.1 .463^{34}$.

392 
395 1. (EDF) Environmental Defense Fund. Sustainable Fisheries Map:

396 http://fisherysolutionscenter.edf.org/map. (2018).

397 2. Chu, C. Thirty years later: The global growth of ITQs and their influence on stock status in marine fisheries. Fish Fish. 10, 217-230 (2009).

399 3. Costello, C., Gaines, S. D. \& Lynham, J. Can catch shares prevent fisheries collapse? $400 \quad$ Science (80-. ). 321, 1678-1681 (2008).

4. Melnychuk, M. C. et al. Can catch share fisheries better track management targets? Fish Fish. 13, 267-290 (2012).

5. Bromley, D. W. Abdicating Responsibility: The Deceits of Fisheries Policy. Fisheries 404 34, 280-290 (2009).

6. Innes, J., Pascoe, S., Wilcox, C., Jennings, S. \& Paredes, S. Mitigating undesirable 406 impacts in the marine environment: A review of market-based management measures. Front. Mar. Sci. 2, 1-12 (2015).

7. Squires, D. et al. Effort rights-based management. Fish Fish. 18, 440-465 (2017).

8. Marchal, P. et al. Impact of technological creep on fishing effort and fishing mortality, for a selection of European fleets. ICES J. Mar. Sci. 64, 192-209 (2007).

411 9. Palomares, M. L. D. \& Pauly, D. On the creeping increase of vessels' fishing power.

412 Ecol. Soc. 24, 4-11 (2019). (2010). 
415 11. Acheson, J., Apollonio, S. \& Wilson, J. Individual transferable quotas and 416 conservation: A critical assessment. Ecol. Soc. 20, (2015).

417 12. Birkenbach, A. M., Kaczan, D. J. \& Smith, M. D. Catch shares slow the race to fish. Nature 544, 223-226 (2017).

13. Arnason, R. Property rights in fisheries: How much can individual transferable quotas 420 accomplish? Rev. Environ. Econ. Policy 6, 217-236 (2012).

14. Branch, T. A. How do individual transferable quotas affect marine ecosystems? Fish 422 Fish. 10, 39-57 (2009).

15. Isaksen, E. T. \& Richter, A. Tragedy, property rights, and the commons: Investigating 424 the causal relationship from institutions to ecosystem collapse. J. Assoc. Environ. Resour. Econ. 6, 741-781 (2019).

426 427

16. Ryan, R. W., Holland, D. S. \& Herrera, G. E. Ecosystem externalities in fisheries. Mar. Resour. Econ. 29, 39-53 (2014).

17. Rahimi, S., Gaines, S. D., Gelcich, S., Deacon, R. \& Ovando, D. Factors driving the implementation of fishery reforms. Mar. Policy 71, 222-228 (2016).

18. Grafton, R. Q. et al. Incentive-based approaches to sustainable fisheries. Can. J. Fish. 431 Aquat. Sci. 63, 699-710 (2006).

19. Arnason, R. Fisheries self-management under ITQs. Mar. Resour. Econ. 22, 373-390 433 (2007).

20. Branch, T. A., Jensen, O. P., Ricard, D., Ye, Y. \& Hilborn, R. Contrasting Global 435 Trends in Marine Fishery Status Obtained from Catches and from Stock Assessments. 
21. Stefansson, G. \& Rosenberg, A. A. Combining control measures for more effective management of fisheries under uncertainty: Quotas, effort limitation and protected areas. Philos. Trans. R. Soc. B Biol. Sci. 360, 133-146 (2005).

22. Branch, T. A., Rutherford, K. \& Hilborn, R. Replacing trip limits with individual transferable quotas: Implications for discarding. Mar. Policy 30, 281-292 (2006).

23. Branch, T. A. \& Hilborn, R. Matching catches to quotas in a multispecies trawl fishery: targeting and avoidance behavior under individual transferable quotas. Can. J. Fish. Aquat. Sci. 65, 1435-1446 (2008).

24. Costello, C., Lynham, J., Lester, S. E. \& Gaines, S. D. Economic Incentives and Global Fisheries Sustainability. Annu. Rev. Resour. Econ. 2, 299-318 (2010).

25. Le Bris, A. et al. Climate vulnerability and resilience in the most valuable North American fishery. Proc. Natl. Acad. Sci. U. S. A. 115, 1831-1836 (2018).

26. Costello, C. \& Grainger, C. Property rights, regulatory capture, and exploitation of natural resources. J. Assoc. Environ. Resour. Econ. 5, (2018).

27. Melnychuk, M. C. et al. Which design elements of individual quota fisheries help to achieve management objectives? Fish Fish. 17, 126-142 (2016).

28. Essington, T. E. Ecological indicators display reduced variation in North American catch share fisheries. Proc. Natl. Acad. Sci. 107, 754-759 (2010).

29. Essington, T. E. et al. Catch shares, fisheries, and ecological stewardship: A comparative analysis of resource responses to a rights-based policy instrument. 
30. Garcia, S. M., Ye, Y., Rice, J. \& Charles, A. Rebuilding of marine fisheries Part 1:

31. Verbeke, G. \& Molenberghs, G. Linear Mixed Models for Longitudinal Data.

461 (Springer-Verlag, 2009).

32. Shadish, W. R., Cook, T. D. C. \& Campbell, D. T. Quasi-Experimental Designs for Generalized Causal Inference. (Houghton Mifflin, 2004).

464 33. Brooks, M. E. et al. glmmTMB balances speed and flexibility among packages for zero-inflated generalized linear mixed modeling. $R J$. 9, 378-400 (2017).

466 34. R Core Team. R studio. (2017).

467 35. Parkes, G. et al. The effects of catch share management on MSC certification scores.

468 Fish. Res. 182, 18-27 (2016).

469

470 


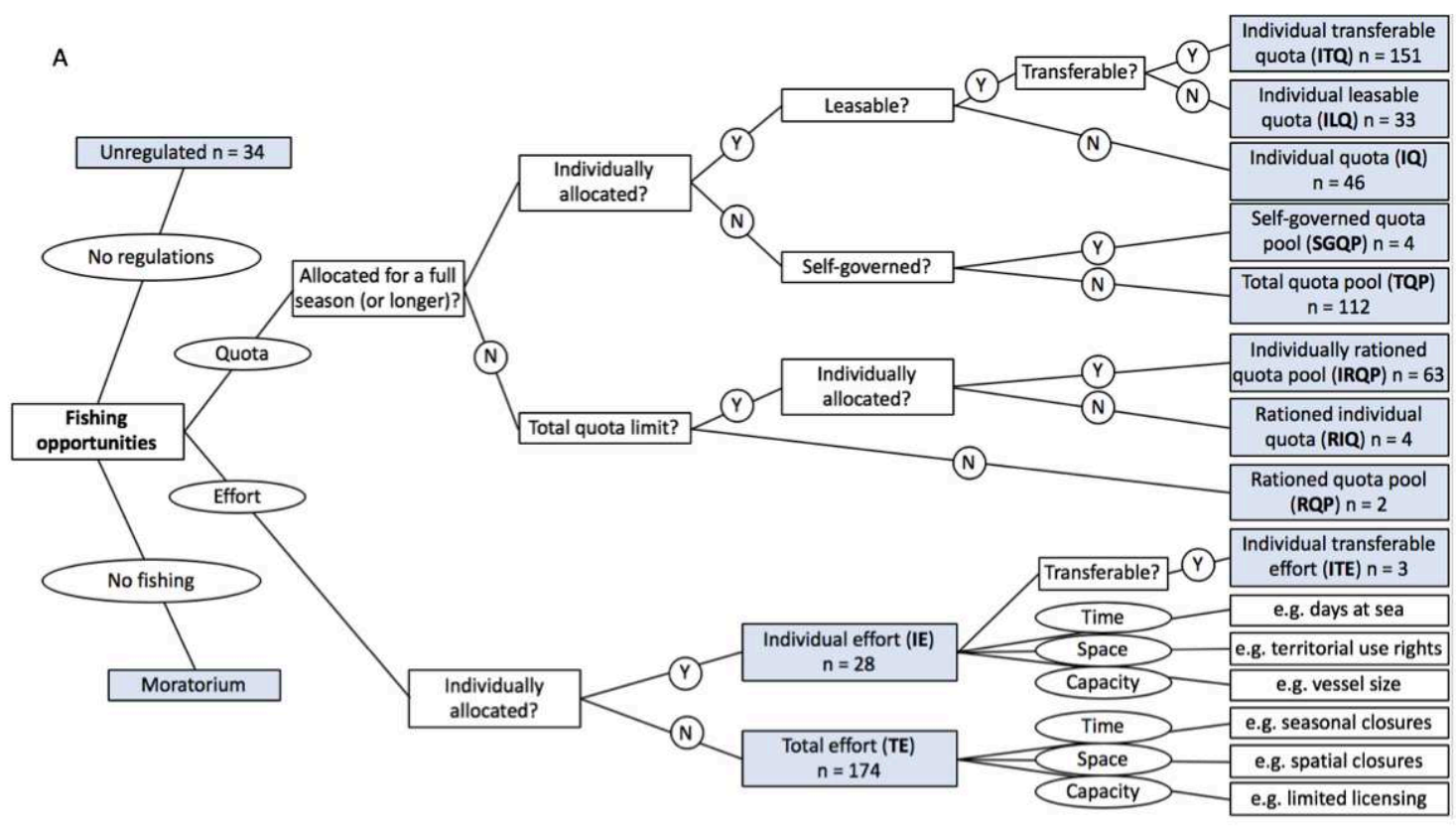

472

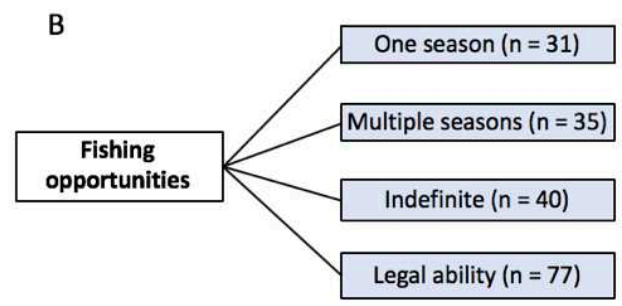

473 Figure 1. A) The classification decision tree for fisheries management systems based on their

474 attributes. The dark-blue terms are the 12 exhaustive classifications used in this study. B) The

475 classification decision tree for the duration of fishing opportunities. Definitions used for the

476 classifications are recorded in Table A1. For each exhaustive classification the number of

477 unique stocks and management classifications that occurred in the dataset are noted. 
Table 1. Empirical research linking attributes of fisheries management systems to sustainable fishing.

\begin{tabular}{|c|c|c|c|c|c|c|c|c|}
\hline Study & Coverage & $\begin{array}{l}\text { Dependent } \\
\text { variable }\end{array}$ & Method & $\begin{array}{l}\text { Individual } \\
\text { allocation }\end{array}$ & $\begin{array}{c}\text { Transfera } \\
\text { bility }\end{array}$ & Quota & Duration & $\begin{array}{c}\text { Multiple } \\
\text { attributes }\end{array}$ \\
\hline 3 & 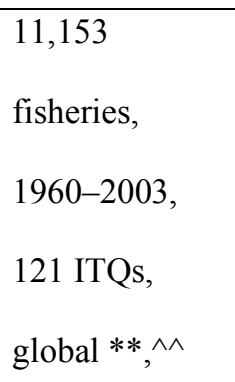 & $\begin{array}{l}\text { Collapsed } \\
\text { landings } \\
\text { (binary) }\end{array}$ & $\begin{array}{l}\text { Difference } \\
\text {-in- } \\
\text { difference } \\
\text { s }\end{array}$ & - & - & - & - & $\begin{array}{l}\text { ITQ: Lower } \\
\text { probability of } \\
\text { collapse }\end{array}$ \\
\hline 2 & $\begin{array}{l}20 \text { ITQ stocks, } \\
\text { global, from } \\
16 \text { to } 36 \text { years } \\
*, \wedge\end{array}$ & $\begin{array}{l}\text { Biomass } \\
\text { change }\end{array}$ & $\begin{array}{l}\text { Descriptiv } \\
\mathrm{e}\end{array}$ & - & - & - & - & $\begin{array}{l}\text { ITQ: Mixed } \\
\text { effect }\end{array}$ \\
\hline 24 & 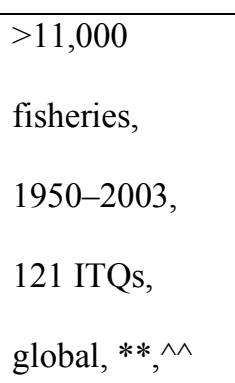 & $\begin{array}{l}\text { Collapsed } \\
\text { landings } \\
\text { (binary) }\end{array}$ & $\begin{array}{l}\text { Difference } \\
\text {-in- } \\
\text { difference } \\
\text { s (subset) }\end{array}$ & - & - & $\begin{array}{l}\text { Lower } \\
\text { probab } \\
\text { ility of } \\
\text { collaps } \\
\text { e }\end{array}$ & - & $\begin{array}{l}\text { IT: Lower } \\
\text { probability of } \\
\text { collapse }\end{array}$ \\
\hline 28 & $\begin{array}{l}15 \mathrm{IQ} / \mathrm{ITQ} \text { in } \\
\text { North America } \\
*, \wedge\end{array}$ & $\begin{array}{l}\text { Landings, } \\
\text { mortality, } \\
\text { biomass, } \\
\text { habitat- } \\
\text { damaging } \\
\text { gear, } \\
\text { discards, } \\
\text { catch:quota }\end{array}$ & $\begin{array}{l}\text { Before } \\
\text { after } \\
\text { control } \\
\text { impact }\end{array}$ & - & - & - & - & $\begin{array}{l}\text { IQ/ILQ/ITQ: } \\
\text { Lower } \\
\text { variability of } \\
\text { mortality and } \\
\text { biomass, no } \\
\text { effect on } \\
\text { mortality or } \\
\text { biomass }\end{array}$ \\
\hline 4 & $\begin{array}{l}345 \text { stocks, } \\
\text { global, } 2000- \\
2004 * * * \wedge\end{array}$ & $\begin{array}{l}\text { Catch:quota, } \\
\text { F:Ftarget, } \\
\text { B:Btarget }\end{array}$ & $\begin{array}{l}\text { 1) Fixed- } \\
\text { effects } \\
\text { models, 2) } \\
\text { mixed- }\end{array}$ & $\begin{array}{l}\text { Lower } \\
\text { catch:quota } \\
\text {, lower } \\
\text { probability }\end{array}$ & - & $\begin{array}{l}\text { Lower } \\
\text { mortali } \\
\text { ty, no } \\
\text { effect }\end{array}$ & - & $\begin{array}{l}\text { IQ/ILQ/ITQ: } \\
\text { Lower } \\
\text { variability of } \\
\text { catch:quota, }\end{array}$ \\
\hline
\end{tabular}




\begin{tabular}{|c|c|c|c|c|c|c|c|c|}
\hline & & & $\begin{array}{l}\text { effects } \\
\text { models, 3) } \\
\text { propensity } \\
\text { score } \\
\text { matching }\end{array}$ & $\begin{array}{l}\text { of high } \\
\text { overfishing }\end{array}$ & & $\begin{array}{l}\text { on } \\
\text { biomas } \\
\text { s }\end{array}$ & & $\begin{array}{l}\text { lower } \\
\text { mortality, no } \\
\text { effect on } \\
\text { biomass }\end{array}$ \\
\hline 29 & $\begin{array}{l}84 \mathrm{IQ} / \mathrm{ITQ} \text { and } \\
140 \text { reference } \\
\text { fisheries } * * * \wedge\end{array}$ & $\begin{array}{l}\text { Landings, } \\
\text { mortality, } \\
\text { biomass }\end{array}$ & $\begin{array}{l}\text { Difference } \\
\text {-in- } \\
\text { difference } \\
\mathrm{s} \\
\text { (Bayesian } \\
\text { ) }\end{array}$ & - & - & - & $\begin{array}{l}\text { Lower } \\
\text { variability } \\
\text { of } \\
\text { landings } \\
\text { and } \\
\text { mortality }\end{array}$ & $\begin{array}{l}\text { IQ/ILQ/ITQ: } \\
\text { Lower } \\
\text { variability of } \\
\text { landings and } \\
\text { mortality, no } \\
\text { effect on } \\
\text { mortality or } \\
\text { biomass }\end{array}$ \\
\hline 27 & $\begin{array}{l}167 \text { stocks, } \\
\text { global, 2000- } \\
2004 \text { ***,^}\end{array}$ & $\begin{array}{l}\text { Catch:quota, } \\
\text { F:Ftarget, } \\
\text { B:Btarget }\end{array}$ & $\begin{array}{l}\text { 1) mixed- } \\
\text { effects } \\
\text { models 2) } \\
\text { random } \\
\text { forest } \\
\text { models }\end{array}$ & $\begin{array}{l}\text { No } \\
\text { independen } \\
\text { t effect of } \\
\text { exclusivity }\end{array}$ & $\begin{array}{l}\text { Lower } \\
\text { biomass }\end{array}$ & - & No effect & - \\
\hline 35 & $\begin{array}{l}298 \text { MSC- } \\
\text { certified } \\
\text { fisheries, } 170 \\
\text { ITQ/IQ/TURF } \\
\text { fisheries, } 136 \\
\text { which are } \\
\text { "SET" ****, } \\
\wedge \wedge\end{array}$ & $\begin{array}{l}\text { MSC } \\
\text { certification } \\
\text { scores } \\
\text { (includes } \\
\text { stock } \\
\text { assessments) }\end{array}$ & $\begin{array}{l}\text { 1) } \\
\text { Bayesian } \\
\text { belief } \\
\text { networks, } \\
\text { 2) } \\
\text { statistical } \\
\text { associatio } \\
\mathrm{n}\end{array}$ & - & - & - & - & $\begin{array}{l}\text { IQ/ILQ/ITQ/T } \\
\text { URF: Higher } \\
\text { probability of } \\
\text { high MSC } \\
\text { score for stock } \\
\text { assessment }\end{array}$ \\
\hline 26 & $\begin{array}{l}178 \text { fisheries, } \\
27 \text { countries. } \\
78 \text { transition to }\end{array}$ & Mortality & $\begin{array}{l}\text { 1) } \\
\text { Regressio } \\
\mathrm{n}, 2 \text { ) non- }\end{array}$ & - & - & - & - & $\begin{array}{l}\text { IQ/ILQ/ITQ/T } \\
\text { URF: Lower } \\
\text { mortality on }\end{array}$ \\
\hline
\end{tabular}




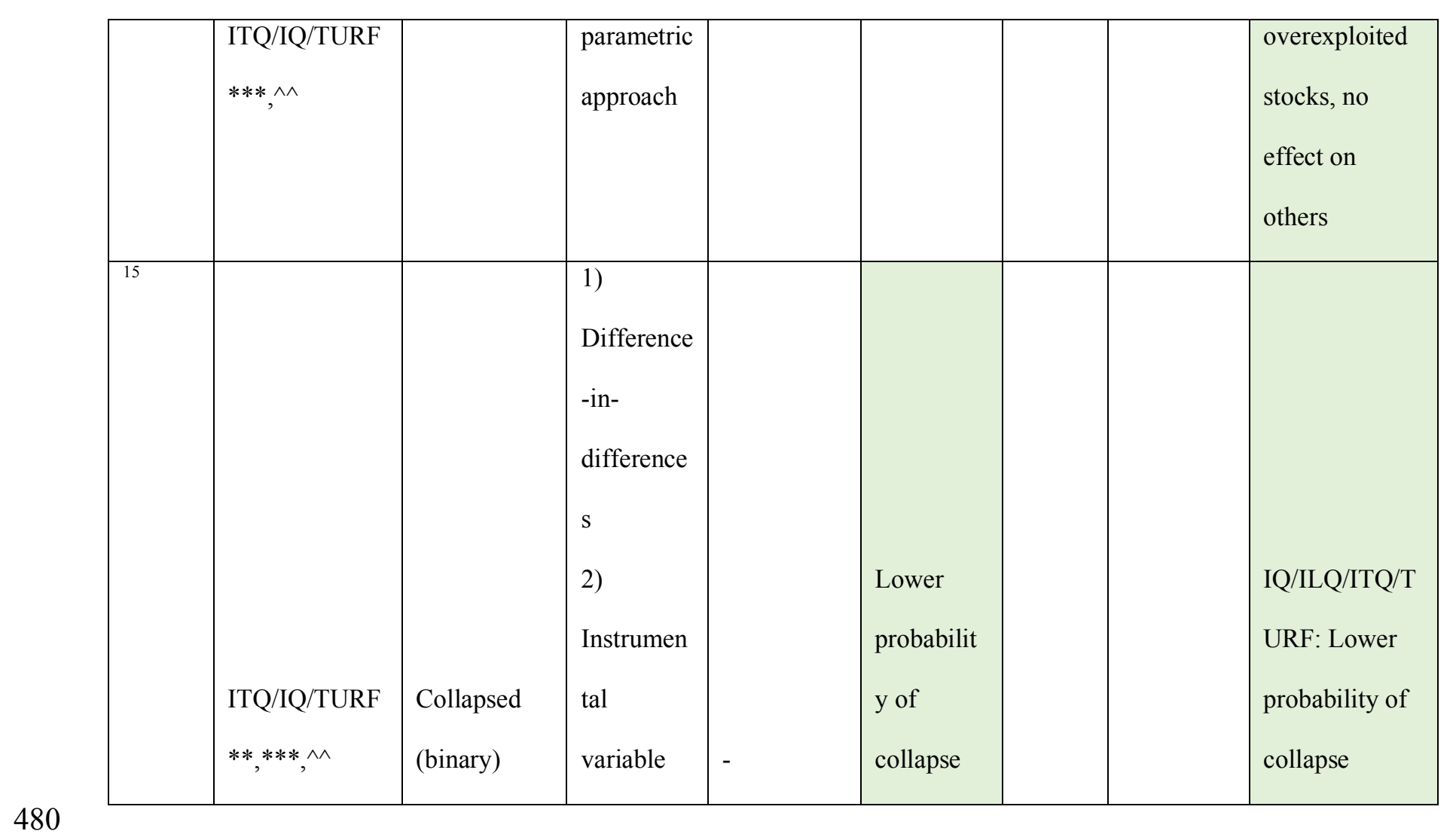

481 Biological data

$482 * \quad$ Manual

$483 \quad * * \quad$ Sea Around Us database (http://www.seaaroundus.org/)

$484 \quad * * * \quad$ RAM legacy database (https://www.ramlegacy.org/)

$485 * * * * \quad$ MSC fisheries database

486 Classification data

$487 \wedge \quad$ Manual

$488 \wedge \quad$ EDF catch share database (http://fisherysolutionscenter.edf.org/database) 
A

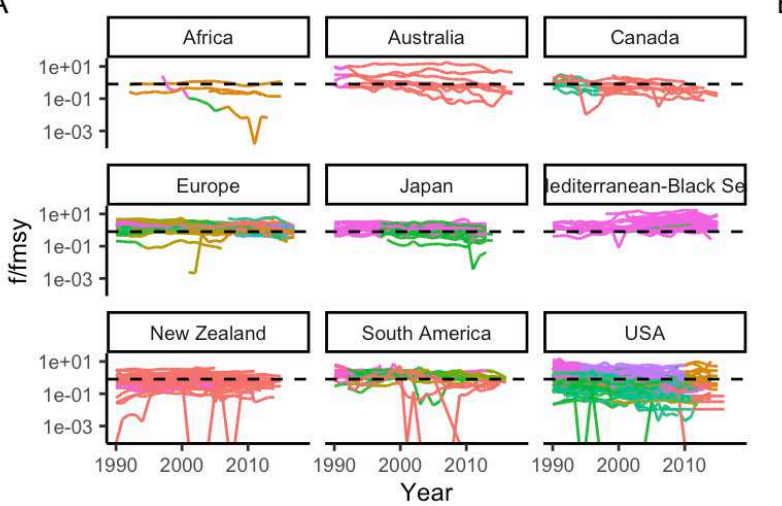

B
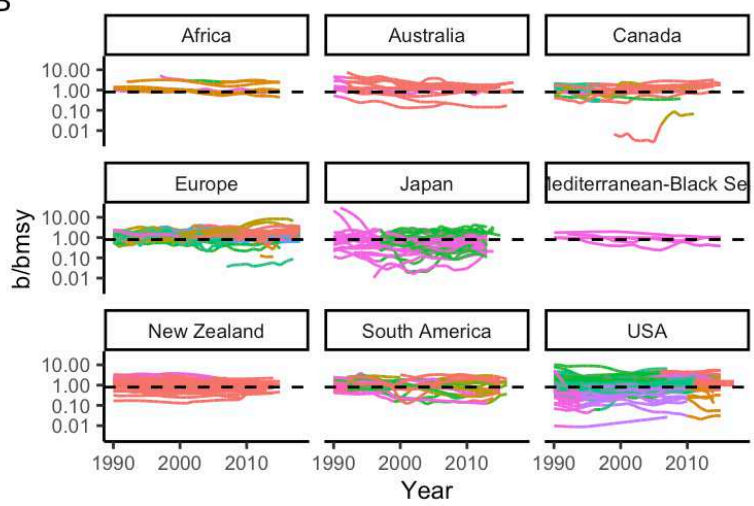

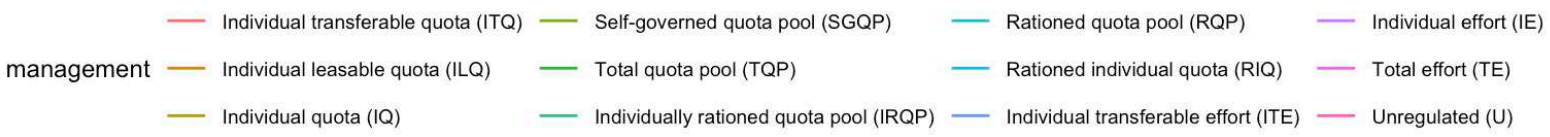

C

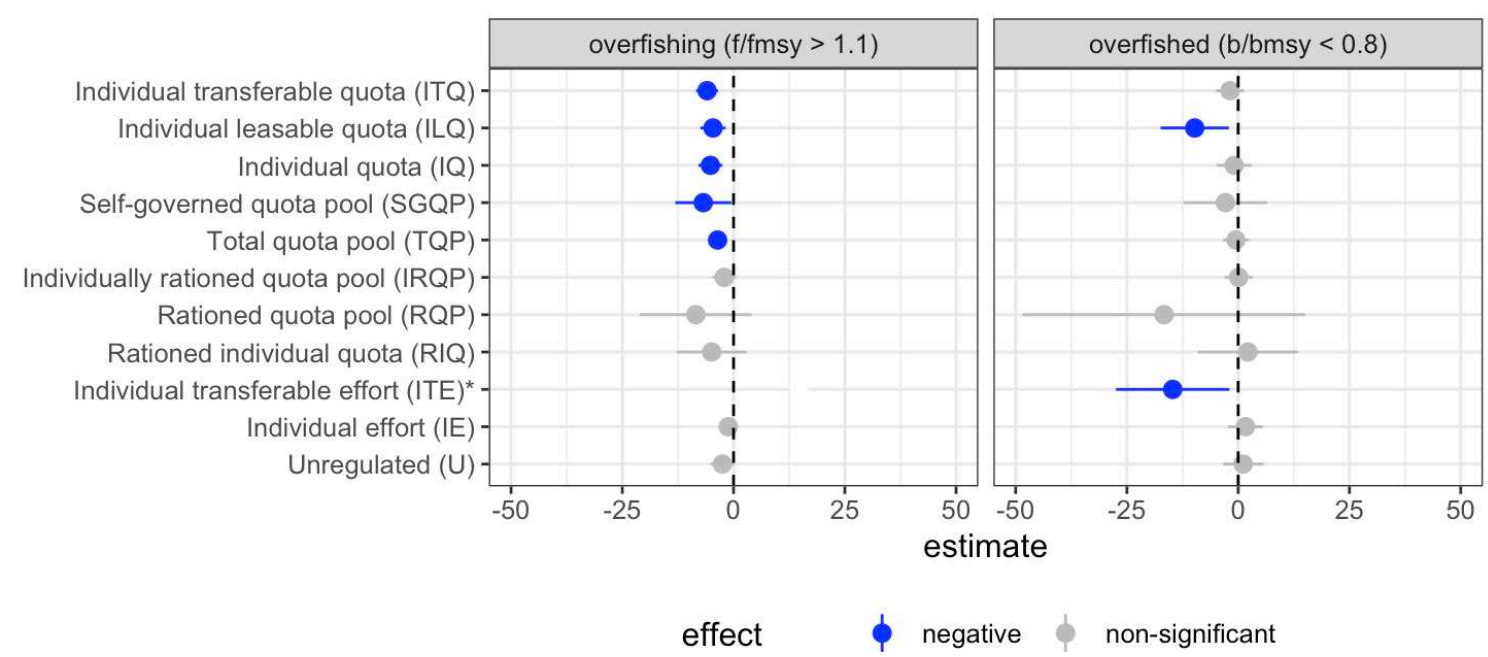

492 Figure 2. A) F/ $\mathrm{F}_{\text {msy }}$ for all classified fisheries management systems (dotted line indicates the threshold

493 for overfishing, i.e., when $\mathrm{F} / \mathrm{F}_{\mathrm{msy}}=1.1$. B). $\mathrm{B} / \mathrm{B}_{\mathrm{msy}}$ for all classified fisheries management systems

494 (dotted line indicates the threshold for overfished, i.e., when $\mathrm{B} / \mathrm{B}_{\mathrm{msy}}=0.8$ ). C) Estimates and 95 percent

495 confidence intervals of management systems compared to TE. Negative (blue) values indicate that the

496 management system reduces the probability of the outcome variable, for example IQ reduces the

497 probability of overfishing compared to TE. The non-significant effect for ITE cannot be displayed in

498 the figure due to wide standard errors (Table B1). 

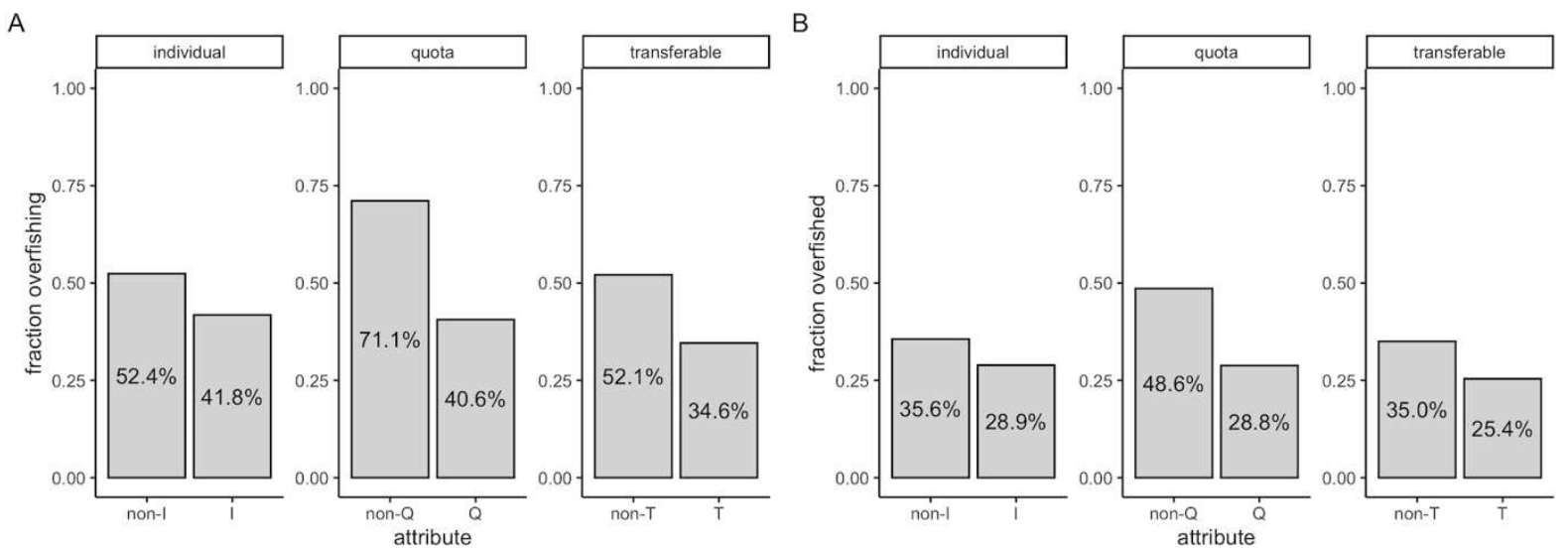

C
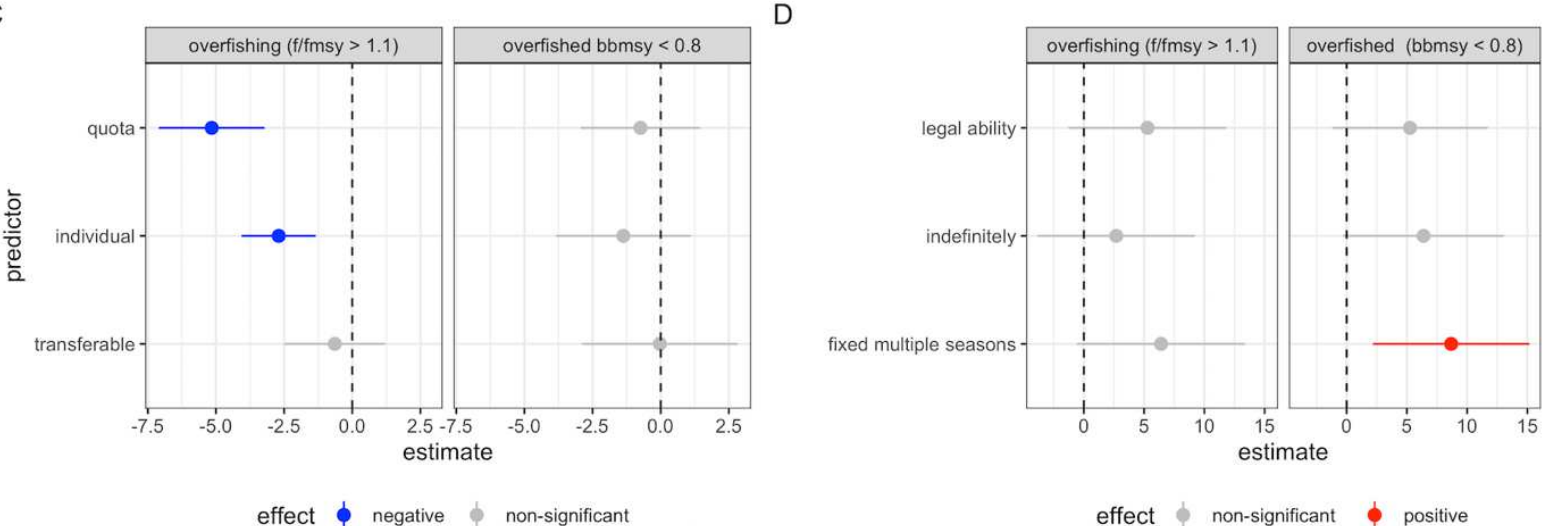

501 Figure 3. A) frequency of overfishing $\left(\mathrm{F} / \mathrm{F}_{\mathrm{msy}}>1.1\right)$ and $\left.\mathrm{B}\right)$ frequency of overfished observations

$502\left(\mathrm{~B} / \mathrm{B}_{\mathrm{msy}}<0.8\right)$ for the attributes I, T, and Q. Each observation is a stock-year combination. C) Mixed-

503 effects results for the attributes I, T, and Q. Negative (blue) effects indicate a reduced probability of

504 overfishing for I and Q (overfishing: 343 stocks with 6803 observations; overfished: 299 stocks with 5056875 observations). D) Effects for the duration of fishing opportunities compared to a single season.

506 The positive (red) value indicates an increased probability of the overfished state for fixed multiple 507 seasons. 

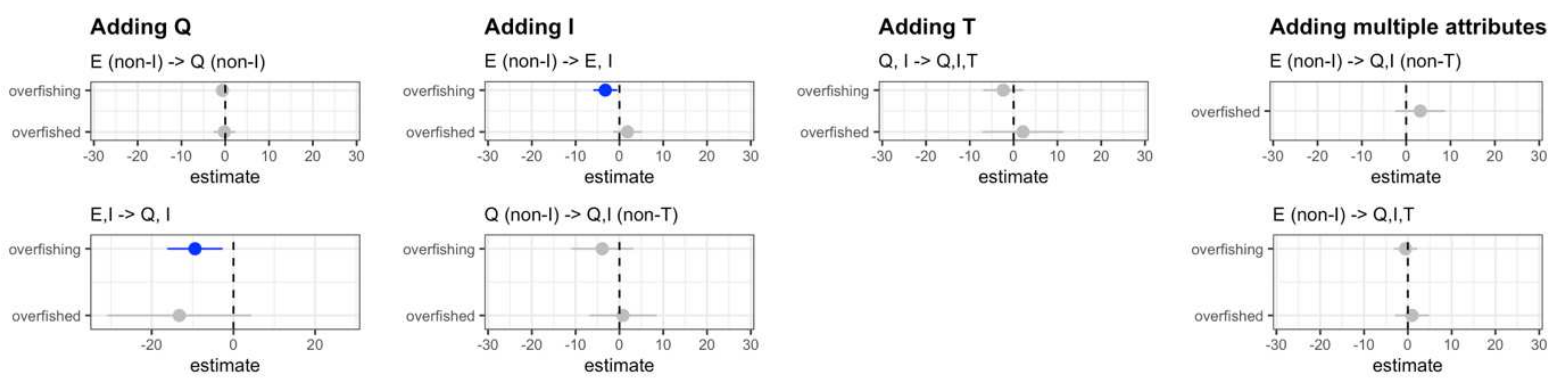

510
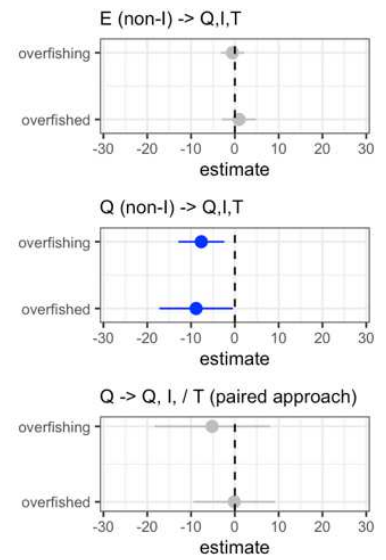

511 Figure 4. DiD estimates of treatment effects, outcomes for the probability of overfishing and overfished

512 outcomes. DiD estimates are indicated for the addition of Q (TE systems transitioning to pooled quota

513 systems, IE systems transitioning to individual quota systems), I (TE systems transitioning to IE, pooled

514 quota systems transitioning to individual (non-transferable) quota systems, $\mathrm{T}$ (individual quota systems

515 transitioning to ITQ systems), and multiple attributes simultaneously. Negative (blue) values indicate

516 that the attribute reduced the probability of the outcome variable. 
Table A1: Management system definitions, for the 12 final management systems and the 4

types of duration of harvesting rights.

\begin{tabular}{|c|c|}
\hline $\begin{array}{l}\text { Management } \\
\text { system }\end{array}$ & Definition \\
\hline $\begin{array}{l}\text { Individual } \\
\text { Transferable } \\
\text { Quota }\end{array}$ & $\begin{array}{l}\text { A quantity limit on catches/landings is allocated for the exclusive use of a vessel/license } \\
\text { and can be sold to a different vessel/license (quota swapping and leasing may also be } \\
\text { permitted). }\end{array}$ \\
\hline $\begin{array}{l}\text { Individual } \\
\text { Leasable Quota }\end{array}$ & $\begin{array}{l}\text { A quantity limit on catches/landings is allocated for the exclusive use of a vessel/license } \\
\text { and can be sold to a different vessel/license for a fixed time period only (quota swapping } \\
\text { may also be permitted but permanent transfer is not). }\end{array}$ \\
\hline Individual Quota & $\begin{array}{l}\text { A quantity limit on catches/landings is allocated for the exclusive use of a vessel/license } \\
\text { and can be swapped for other quota but cannot be leased or permanently sold (i.e. monetary } \\
\text { transfers). }\end{array}$ \\
\hline $\begin{array}{l}\text { Self-Governed } \\
\text { Quota Pool(s) }\end{array}$ & $\begin{array}{l}\text { A quantity limit on catches/landings is allocated to a group of vessels/licenses for joint use. } \\
\text { The pool is managed by its membership. Fishers have no individual holdings to enter/exit } \\
\text { the pool. }\end{array}$ \\
\hline Total Quota Pool & $\begin{array}{l}\text { A quantity limit on catches/landings is allocated to a group of vessels/licenses for joint use. } \\
\text { The pool is managed by the government. }\end{array}$ \\
\hline $\begin{array}{l}\text { Individually- } \\
\text { Rationed Quota } \\
\text { Pool }\end{array}$ & $\begin{array}{l}\text { A quantity limit on catches/landings is allocated to a group of vessels/licenses for joint use. } \\
\text { These limits are allocated to individual vessels/licenses for exclusive use in multiple time } \\
\text { periods within a fishing season (e.g. daily, weekly or monthly limits). }\end{array}$ \\
\hline $\begin{array}{l}\text { Rationed Quota } \\
\text { Pool }\end{array}$ & $\begin{array}{l}\text { A quantity limit on catches/landings is allocated to a group of vessels/licenses for joint use. } \\
\text { These limits are administered in multiple time periods within a fishing season (e.g. weekly } \\
\text { or monthly vessel limits). }\end{array}$ \\
\hline $\begin{array}{l}\text { Rationed } \\
\text { Individual Quota }\end{array}$ & $\begin{array}{l}\text { A quantity limit on catches/landings is allocated for the exclusive use of a vessel/license. } \\
\text { These limits are administered in multiple time periods within a fishing season (e.g. weekly } \\
\text { or monthly vessel limits). There is no total quota limit that can be reached, meaning there is } \\
\text { no pool and each vessel/license limit is independent. }\end{array}$ \\
\hline $\begin{array}{l}\text { Individual } \\
\text { Transferable } \\
\text { Effort }\end{array}$ & \begin{tabular}{|l} 
A limit on fisheries inputs (e.g. days at sea, area/territory, vessel capacity) is allocated for \\
the exclusive use of a vessel/license and can be sold to a different vessel/license.
\end{tabular} \\
\hline Individual Effort & \begin{tabular}{|l} 
A limit on fisheries inputs (e.g. days at sea, area/territory, vessel capacity) is allocated for \\
the exclusive use of a vessel/license.
\end{tabular} \\
\hline Total Effort & \begin{tabular}{|l} 
A limit on fisheries inputs (e.g. number of vessels, days at sea, vessel capacity, seasonal \\
closure, spatial closure) is set for the entire fishery.
\end{tabular} \\
\hline Unregulated & There is no fisheries legislation limiting the amount of fishing pressure. \\
\hline Duration & Definition \\
\hline Indefinite & $\begin{array}{l}\text { In fisheries legislation it is specified that fishing opportunities are held permanently. The } \\
\text { size of the fishing opportunity may change as the total changes (e.g. } 3 \% \text { of } 100 \text { may } \\
\text { become } 3 \% \text { of } 150 \text { ), but fishing opportunity does not change as a relative share of the total. } \\
\text { Fishing licenses may be subject to change at a different interval. }\end{array}$ \\
\hline $\begin{array}{l}\text { Fixed multiple } \\
\text { seasons }\end{array}$ & $\begin{array}{l}\text { In fisheries legislation it is specified that fishing opportunities are held for a fixed period } \\
\text { that spans multiple fishing seasons (e.g. } 10 \text { years) after which the relative shares of fishing } \\
\text { opportunities may be revised. Fishing licenses may be subject to change at a different } \\
\text { interval. }\end{array}$ \\
\hline One season & $\begin{array}{l}\text { In fisheries legislation it is specified that fishing opportunities are held for one season (e.g. } \\
\text { one year) after which the relative shares of fishing opportunities may be revised. Fisheries } \\
\text { legislation requires an active decision each year on allocations (i.e. the default is not }\end{array}$ \\
\hline
\end{tabular}




\begin{tabular}{|l||l|}
\hline & $\begin{array}{l}\text { necessarily the same allocation as the previous year). Fishing licenses may be subject to } \\
\text { change at a different interval. }\end{array}$ \\
\hline & $\begin{array}{l}\text { In fisheries legislation it is specified that the fisheries manager reserves the right to revise } \\
\text { the relative shares of fishing opportunities, but as the duration of the fishing opportunities } \\
\text { is not specified this can take place at any time. Fisheries legislation does not require an } \\
\text { active decision each year on allocations (i.e. the default is the same allocation as the } \\
\text { previous year). Fishing licenses may be subject to change at a different interval. }\end{array}$ \\
\hline
\end{tabular}

523 Table A2: Treatment and control stocks for paired difference in difference analysis.

\begin{tabular}{|c|c|c|c|c|c|c|}
\hline $\begin{array}{l}\text { Treatment/ } \\
\text { control }\end{array}$ & Did code & stock name RAM & $\begin{array}{l}\text { year } \\
\text { of } \\
\text { quota }\end{array}$ & $\begin{array}{l}\text { year of } \\
\text { IQ }\end{array}$ & $\begin{array}{l}\text { minimum } \\
\text { year used }\end{array}$ & $\begin{array}{l}\text { final year } \\
\text { used }\end{array}$ \\
\hline impact & sa1 & $\begin{array}{l}\text { Sablefish Eastern Bering Sea } \\
\text { / Aleutian Islands / Gulf of } \\
\text { Alaska }\end{array}$ & 1977 & 1995 & 1982 & 2011 \\
\hline control & sal & Sablefish Pacific Coast & 1982 & 2011 & 1982 & 2011 \\
\hline impact & $\mathrm{sa} 2$ & $\begin{array}{l}\text { Sablefish Pacific Coast of } \\
\text { Canada }\end{array}$ & 1981 & 1990 & 1982 & 2011 \\
\hline control & $\mathrm{sa} 2$ & Sablefish Pacific Coast & 1982 & 2011 & 1982 & 2011 \\
\hline impact & gh1 & $\begin{array}{l}\text { Greenland halibut NAFO } \\
\text { 4RST }\end{array}$ & 1982 & 1995 & 1986 & 2017 \\
\hline control & gh1 & $\begin{array}{l}\text { Greenland halibut Bering Sea } \\
\text { and Aleutian Islands }\end{array}$ & 1986 & no IQ & 1986 & 2017 \\
\hline impact & wp1 & $\begin{array}{l}\text { Walleye pollock Eastern } \\
\text { Bering Sea }\end{array}$ & 1977 & 2000 & 1982 & 2017 \\
\hline control & wp1 & $\begin{array}{l}\text { Walleye pollock Gulf of } \\
\text { Alaska }\end{array}$ & 1977 & no IQ & 1982 & 2017 \\
\hline impact & wp2 & $\begin{array}{l}\text { Walleye pollock Aleutian } \\
\text { Islands }\end{array}$ & 1980 & 2000 & 1982 & 2017 \\
\hline control & wp2 & $\begin{array}{l}\text { Walleye pollock Gulf of } \\
\text { Alaska }\end{array}$ & 1977 & no IQ & 1982 & 2017 \\
\hline impact & pc1 & $\begin{array}{l}\text { Pacific cod West Coast of } \\
\text { Vancouver Island }\end{array}$ & 1979 & 1997 & 1982 & 2008 \\
\hline control & $\mathrm{pc1}$ & Pacific cod Bering Sea & 1977 & 2008 & 1982 & 2008 \\
\hline impact & pc2 & Pacific cod Hecate Strait & 1992 & 1997 & 1992 & 2008 \\
\hline control & pc2 & Pacific cod Bering Sea & 1977 & 2008 & 1992 & 2008 \\
\hline impact & $\mathrm{tfl}$ & Tilefish Mid-Atlantic Coast & 2001 & 2009 & 1994 & 2017 \\
\hline control & $\mathrm{tfl}$ & $\begin{array}{l}\text { Tilefish Southern Atlantic } \\
\text { coast }\end{array}$ & 1994 & no IQ & 1994 & 2017 \\
\hline impact & $\mathrm{tf} 2$ & Tilefish Gulf of Mexico & 2004 & 2010 & 1994 & 2017 \\
\hline control & $\mathrm{tf} 2$ & $\begin{array}{l}\text { Tilefish Southern Atlantic } \\
\text { coast }\end{array}$ & 1994 & no IQ & 1994 & 2017 \\
\hline impact & $\mathrm{rkc1}$ & Red king crab Bristol Bay & 1980 & 2005 & 1982 & 2015 \\
\hline control & $\mathrm{rkc1}$ & Red king crab Norton Sound & 1978 & no IQ & 1982 & 2015 \\
\hline impact & pop1 & $\begin{array}{l}\text { Pacific Ocean perch West } \\
\text { Coast of Vancouver Island }\end{array}$ & 1979 & 1997 & 1982 & 2011 \\
\hline control & pop1 & $\begin{array}{l}\text { Pacific ocean perch Pacific } \\
\text { Coast }\end{array}$ & 1982 & 2011 & 1982 & 2011 \\
\hline impact & ha $a r$ & $\begin{array}{l}\text { Argentine hake Southern } \\
\text { Argentina }\end{array}$ & 1998 & 2010 & 1998 & 2017 \\
\hline control & ha_ar & $\begin{array}{l}\text { Argentine hake Northern } \\
\text { Argentina }\end{array}$ & 1998 & no IQ & 1998 & 2017 \\
\hline
\end{tabular}




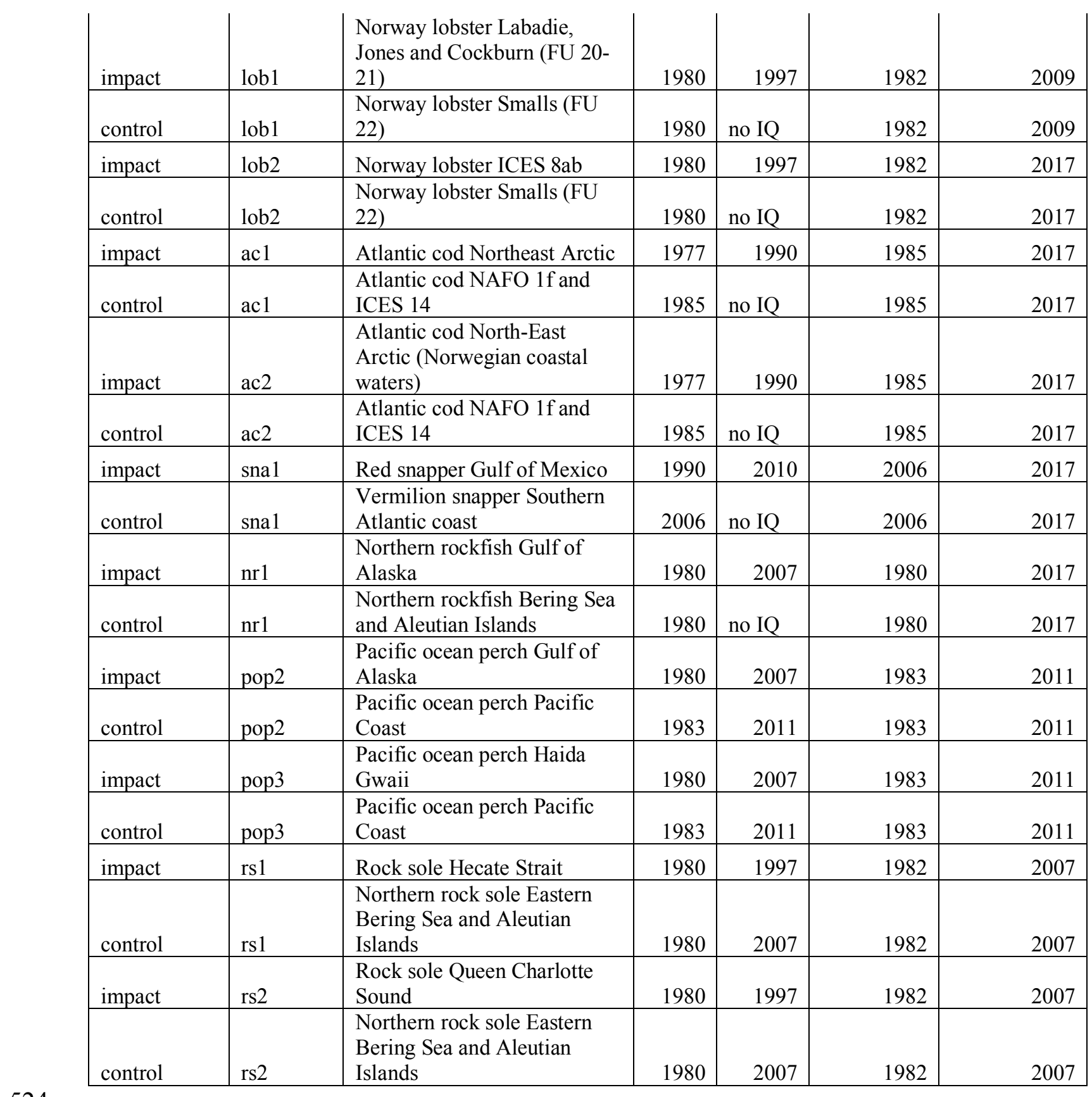


Appendix B. Additional tables and figures and sensitivity analyses

Table B1: Effect sizes, confidence intervals and p-values for the management system model (presented in Figure 2 in the main text). Bolded values are significant at the $p<0.05$ level.

\begin{tabular}{|c|c|c|c|c|c|}
\hline $\begin{array}{l}\text { Outcome } \\
\text { variable }\end{array}$ & Management & estimate & upper CI & $\begin{array}{l}\text { lower } \\
\text { CI }\end{array}$ & probability \\
\hline \multirow{20}{*}{$\begin{array}{l}\text { overfishing } \\
\text { (f/fmsy }> \\
1.1)\end{array}$} & ITQ & -5.96 & -3.50 & -8.42 & $<0.001$ \\
\hline & ILQ & -4.62 & -1.79 & -7.45 & 0.001 \\
\hline & IQ & -5.20 & -2.49 & -7.91 & $<0.001$ \\
\hline & SGQP & -6.81 & -0.52 & -13.10 & 0.03 \\
\hline & TQP & -3.58 & -1.73 & -5.43 & $<0.001$ \\
\hline & IRQP & -2.11 & 0.57 & -4.78 & 0.12 \\
\hline & RIQ & -4.91 & 2.91 & -12.73 & 0.22 \\
\hline & RQP & -8.49 & 4.09 & -21.06 & 0.19 \\
\hline & ITE & 14.70 & 4603.40 & 4574.01 & 0.99 \\
\hline & IE & -1.19 & 0.90 & -3.28 & 0.26 \\
\hline & unregulated & -2.51 & 0.10 & -5.12 & 0.06 \\
\hline & ITQ & -1.85 & 1.34 & -5.05 & 0.26 \\
\hline & ILQ & -9.76 & -2.09 & -17.44 & 0.01 \\
\hline & IQ & -0.89 & 3.05 & -4.83 & 0.66 \\
\hline & SGQP & -2.85 & 6.51 & -12.21 & 0.55 \\
\hline & TQP & -0.50 & 2.42 & -3.42 & 0.74 \\
\hline & IRQP & 0.10 & 3.26 & -3.06 & 0.95 \\
\hline & RIQ & 2.19 & 13.38 & -9.01 & 0.70 \\
\hline & RQP & -16.66 & 15.09 & -48.41 & 0.30 \\
\hline & ITE & -14.71 & -1.95 & -27.46 & 0.02 \\
\hline \multirow{2}{*}{$\begin{array}{l}\text { overfished } \\
\text { (b/bmsy < } \\
0.8)\end{array}$} & IE & 1.64 & 5.51 & -2.24 & 0.41 \\
\hline & unregulated & 1.13 & 5.66 & -3.41 & 0.63 \\
\hline
\end{tabular}
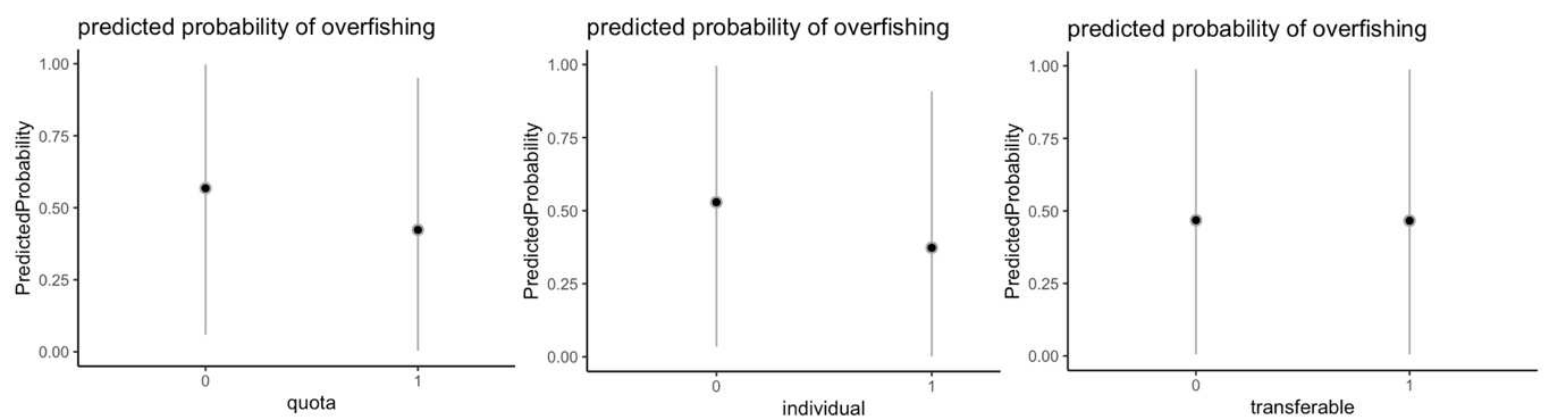

Figure B1: Predicted probabilities of overfishing with without (0) and with (1) quota, individual and transferable attributes.

Table B2: Effect sizes, confidence intervals and p-values for the management system model, sensitivity using fishing mortality and biomass trends. Bolded values are significant at the $538 \mathrm{p}<0.05$ level. 


\begin{tabular}{|c|c|c|c|c|c|}
\hline $\begin{array}{l}\text { Outcome } \\
\text { variable }\end{array}$ & Management & estimate & upper CI & $\begin{array}{l}\text { lower } \\
\text { CI }\end{array}$ & probability \\
\hline \multirow{19}{*}{$\begin{array}{l}\text { decreasing } \\
\text { overfishing } \\
\text { (f/fmsy }> \\
\text { 1.1) }\end{array}$} & ITQ & $\begin{array}{l}-0.89 \\
\end{array}$ & -0.17 & -1.61 & 0.02 \\
\hline & ILQ & -0.97 & 0.03 & -1.98 & 0.06 \\
\hline & IQ & -0.71 & 0.15 & -1.57 & 0.11 \\
\hline & SGQP & -0.47 & 1.62 & -2.55 & 0.66 \\
\hline & TQP & -0.65 & -0.04 & -1.26 & 0.04 \\
\hline & IRQP & -0.05 & 0.77 & -0.88 & 0.90 \\
\hline & RIQ & 0.62 & 3.30 & -2.05 & 0.65 \\
\hline & RQP & -0.48 & 2.41 & -3.36 & 0.75 \\
\hline & ITE & -0.46 & 1.19 & -2.10 & 0.59 \\
\hline & IE & 0.81 & 1.60 & 0.02 & 0.04 \\
\hline & unregulated & 0.33 & 1.51 & -0.85 & 0.59 \\
\hline & ITQ & 0.44 & 2.36 & -1.49 & 0.66 \\
\hline & ILQ & -0.23 & 3.22 & -3.67 & 0.90 \\
\hline & IQ & -0.22 & 2.98 & -3.42 & 0.89 \\
\hline & SGQP & 2.90 & 8.78 & -2.99 & 0.33 \\
\hline & TQP & -0.04 & 2.03 & -2.10 & 0.97 \\
\hline & IRQP & 1.81 & 4.03 & -0.41 & 0.11 \\
\hline & RIQ & -12.26 & 9556.46 & 9580.98 & 1.00 \\
\hline & RQP & -10.22 & 3244.54 & 3264.97 & 1.00 \\
\hline \multirow{3}{*}{$\begin{array}{l}\text { Decreasing } \\
\text { overfished } \\
\text { (b/bmsy< } \\
\text { 0.8) }\end{array}$} & ITE & -0.57 & 4.88 & -6.02 & 0.84 \\
\hline & IE & 0.78 & 3.27 & -1.71 & 0.54 \\
\hline & unregulated & 0.60 & 7.23 & -6.04 & 0.86 \\
\hline
\end{tabular}

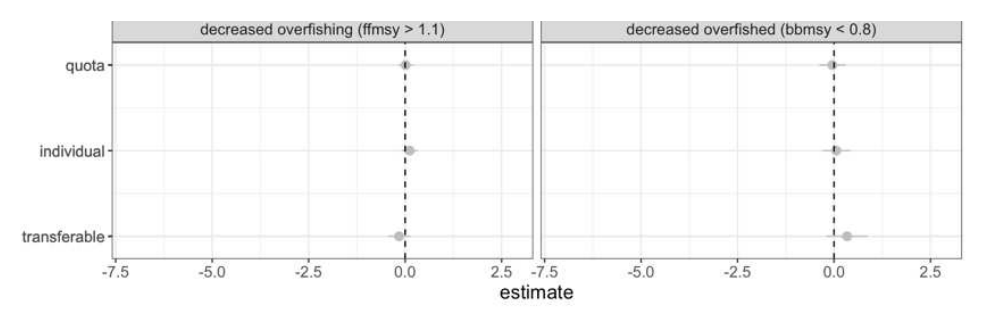

541 Figure B2: Mixed-effects results for the attributes I, T, and Q predicting positive trends in stocks 542 with overfishing (decreased overfishing) or overfished stocks (decreased overfished).

543

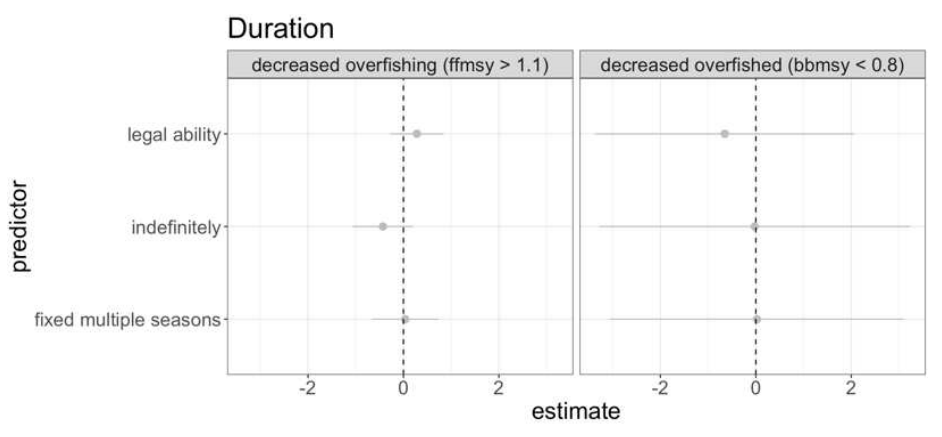


Figure B3: Mixed-effects results for different duration of IQ's predicting positive trends in stocks with overfishing (decreased overfishing) or overfished stocks (decreased overfished).
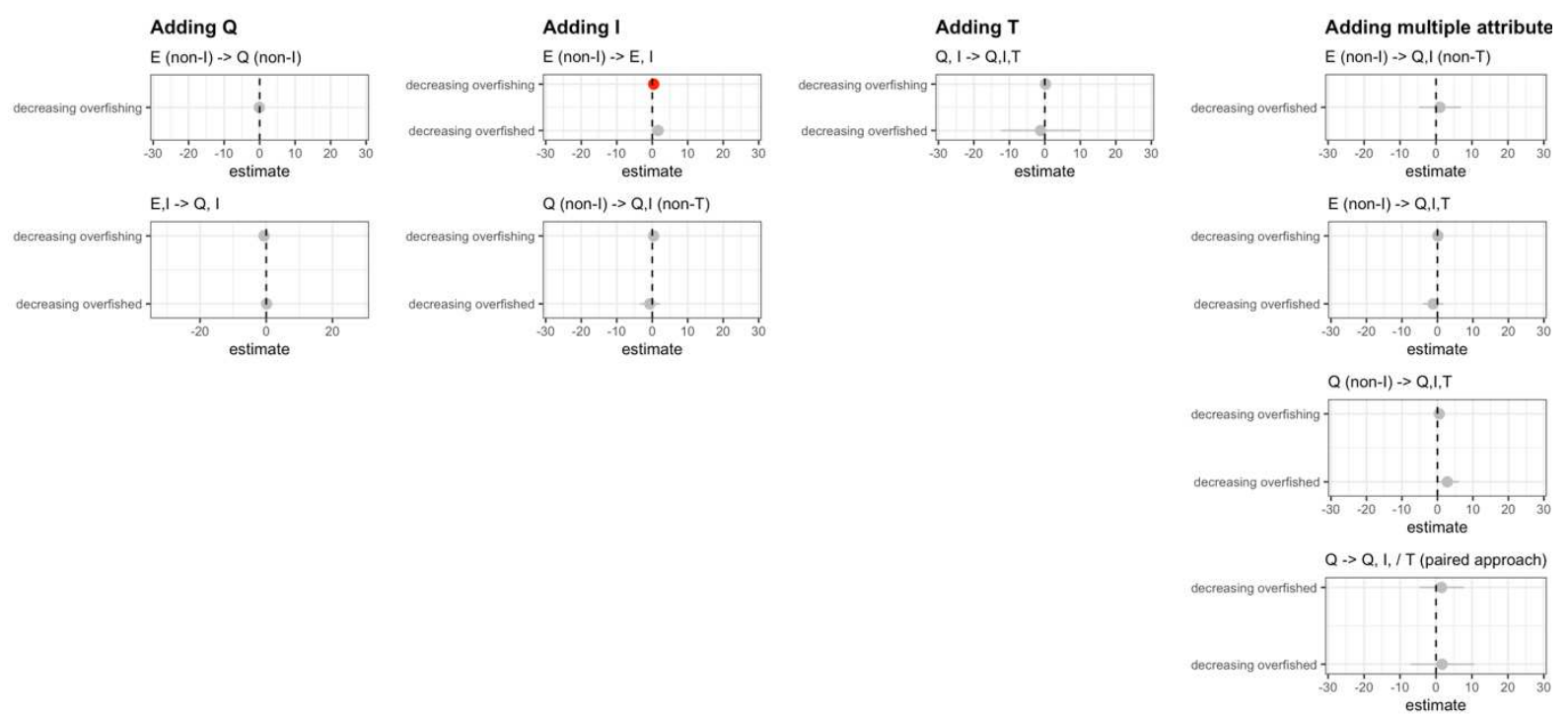

548

549

550

551

552

553

554

555

556

557

558

559
Table B3: Effect sizes and standard errors, confidence intervals and p-values for the management system model, sensitivity predicting high overfishing and high overfished. Bolded values are significant at the $\mathrm{p}<0.05$ level.

\begin{tabular}{llrrrr}
$\begin{array}{l}\text { Outcome } \\
\text { variable }\end{array}$ & Management & estimate & upper CI & lower CI & probability \\
\hline & ITQ & $\mathbf{- 1 2 . 1 6}$ & $\mathbf{- 7 . 3 2}$ & $\mathbf{- 1 6 . 9 9}$ & $<\mathbf{0 . 0 0 1}$ \\
& ILQ & $\mathbf{- 1 1 . 5 3}$ & $\mathbf{- 6 . 1 8}$ & $\mathbf{- 1 6 . 8 8}$ & $<\mathbf{0 . 0 0 1}$ \\
& IQ & $\mathbf{- 1 1 . 5 9}$ & $\mathbf{- 6 . 3 0}$ & $\mathbf{- 1 6 . 8 8}$ & $<\mathbf{0 . 0 0 1}$ \\
High & SGQP & $\mathbf{- 1 2 . 5 1}$ & $\mathbf{- 2 . 8 6}$ & $\mathbf{- 2 2 . 1 6}$ & $\mathbf{0 . 0 1}$ \\
overfishing \\
(F/fmsy & TQP & $\mathbf{- 1 0 . 7 6}$ & $\mathbf{- 6 . 3 2}$ & $\mathbf{- 1 5 . 2 0}$ & $<\mathbf{0 . 0 0 1}$ \\
$>\mathbf{1 . 5 )}$ & IRQP & $\mathbf{- 1 1 . 4 2}$ & $\mathbf{- 6 . 4 7}$ & $\mathbf{- 1 6 . 3 8}$ & $<\mathbf{0 . 0 0 1}$ \\
& RIQ & -1.93 & 9.56 & -13.43 & 0.74 \\
& RQP & -8.26 & 1.73 & -18.26 & 0.11 \\
& ITE & 1.59 & 11.16 & -7.97 & 0.74 \\
& IE & $\mathbf{- 7 . 2 4}$ & $\mathbf{- 3 . 0 4}$ & $\mathbf{- 1 1 . 4 4}$ & $<\mathbf{0 . 0 0 1}$ \\
& unregulated & $\mathbf{- 6 . 4 3}$ & $\mathbf{- 1 . 5 8}$ & $\mathbf{- 1 1 . 2 8}$ & $\mathbf{0 . 0 1}$ \\
\hline
\end{tabular}




\begin{tabular}{llrrrl}
\hline $\begin{array}{l}\text { High } \\
\text { overfished } \\
\text { (b/bmsy }<\end{array}$ & ITQ & 0.51 & 4.88 & -3.86 & 0.82 \\
$\mathbf{0 . 5 )}$ & ILQ & -1.68 & 6.11 & -9.48 & 0.67 \\
& IQ & 0.17 & 6.18 & -5.85 & 0.96 \\
& SGQP & -0.37 & 8.51 & -9.24 & 0.94 \\
& TQP & 1.58 & 5.44 & -2.29 & 0.42 \\
& IRQP & 2.37 & 6.84 & -2.11 & 0.30 \\
& RIQ & -10.80 & 7815.90 & -7837.51 & 1.00 \\
& & & & - & \\
& RQP & -12.14 & 14377.87 & 14402.15 & 1.00 \\
ITE & -1.24 & 15.11 & -17.58 & 0.88 \\
& IE & $\mathbf{5 . 6 5}$ & $\mathbf{9 . 8 7}$ & $\mathbf{1 . 4 2}$ & $\mathbf{0 . 0 1}$ \\
& unregulated & 2.35 & 7.84 & -3.13 & 0.40
\end{tabular}

560

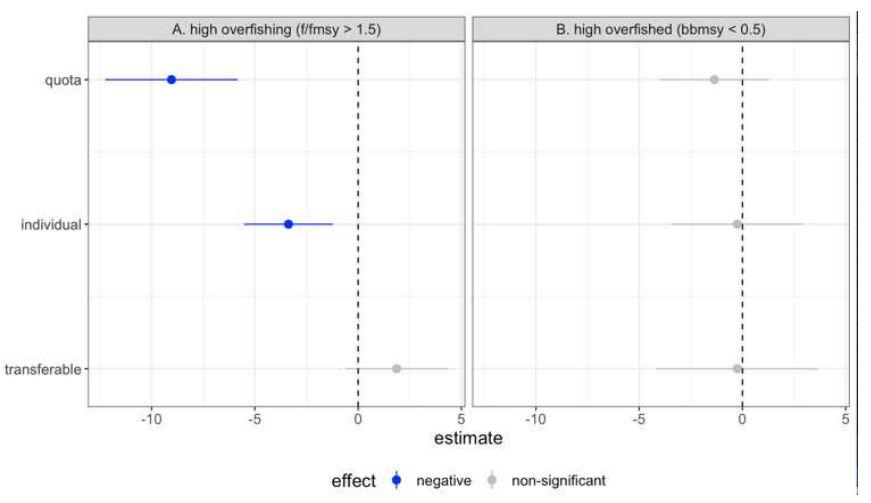

561

562

Figure B5: Mixed-effects results for the attributes I, T, and Q. Negative (blue) effects indicate a

563

564 reduced probability of overfishing for I and Q for high overfishing and highly overfished.

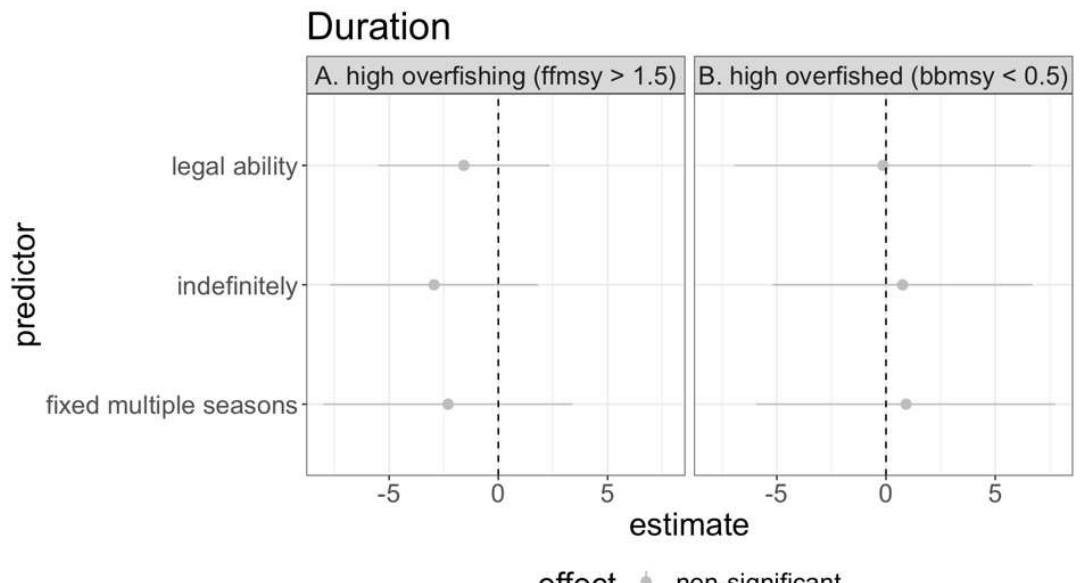

effect $\phi$ non-significant

566 Figure B6: Mixed-effects results for different duration of IQ's for high overfishing and highly overfished. 

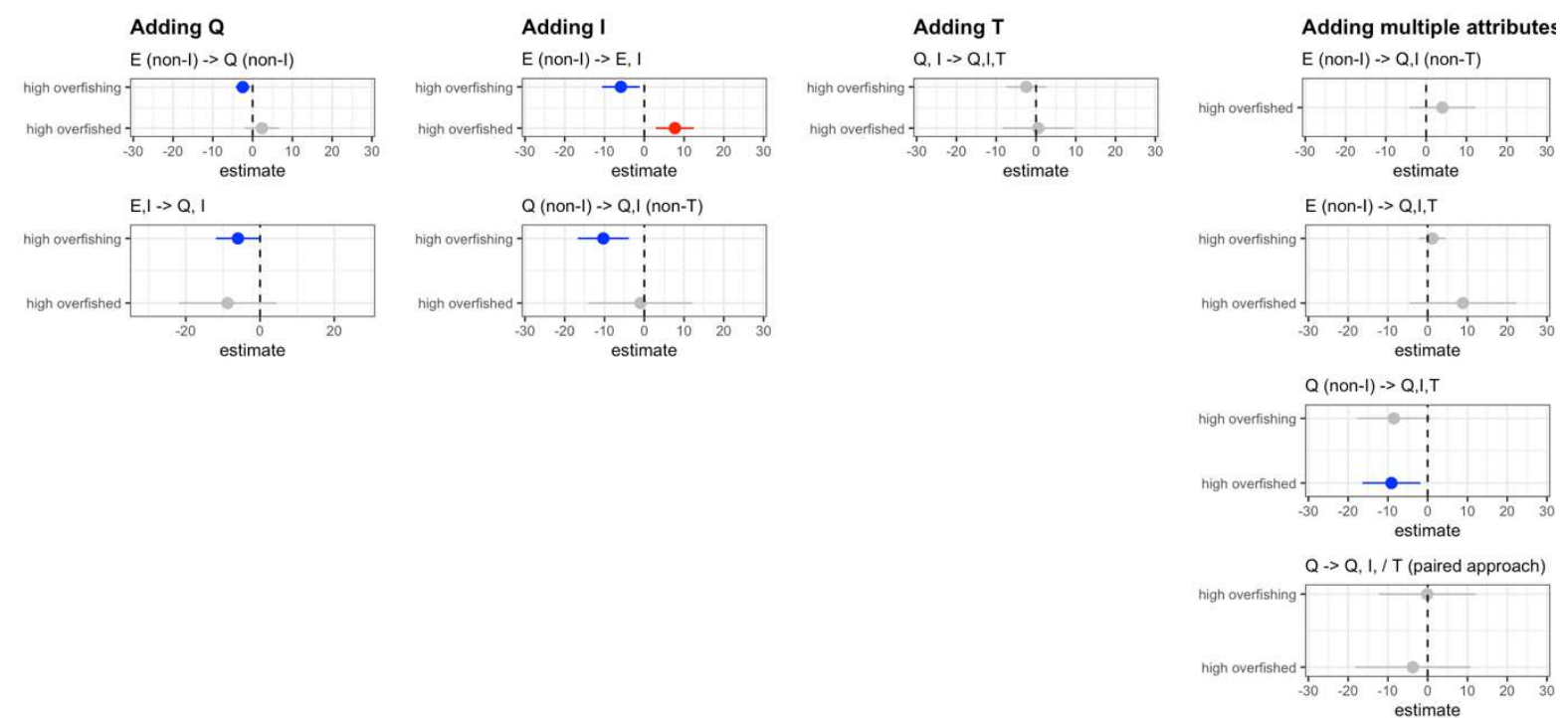

570 Figure B7: DiD estimates of treatment effects, outcomes for the probability of high overfishing and

571 high overfished outcomes. DiD estimates are indicated for the addition of Q (TE systems transitioning

572 to pooled quota systems, IE systems transitioning to individual quota systems), I (TE systems

573 transitioning to IE, pooled quota systems transitioning to individual (non-transferable) quota systems,

$574 \mathrm{~T}$ (individual quota systems transitioning to ITQ systems), and multiple attributes simultaneously.

575 Negative (blue) values indicate that the attribute reduced the probability of the outcome variable. 


\section{Figures}
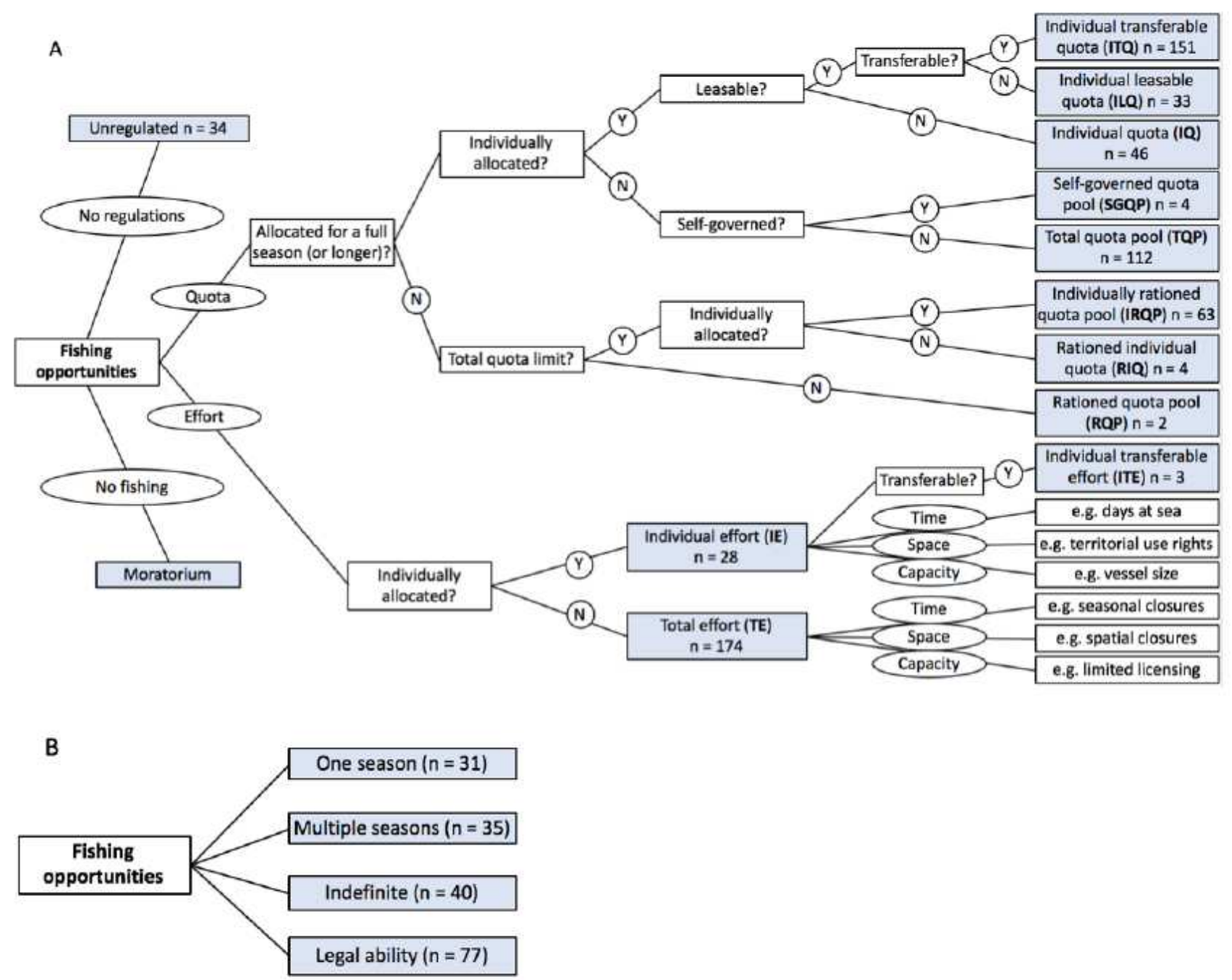

\section{Figure 1}

A) The classification decision tree for fisheries management systems based on their attributes. The darkblue terms are the 12 exhaustive classifications used in this study. B) The classification decision tree for the duration of fishing opportunities. Definitions used for the classifications are recorded in Table A1. For each exhaustive classification the number of unique stocks and management classifications that occurred in the dataset are noted. 
A

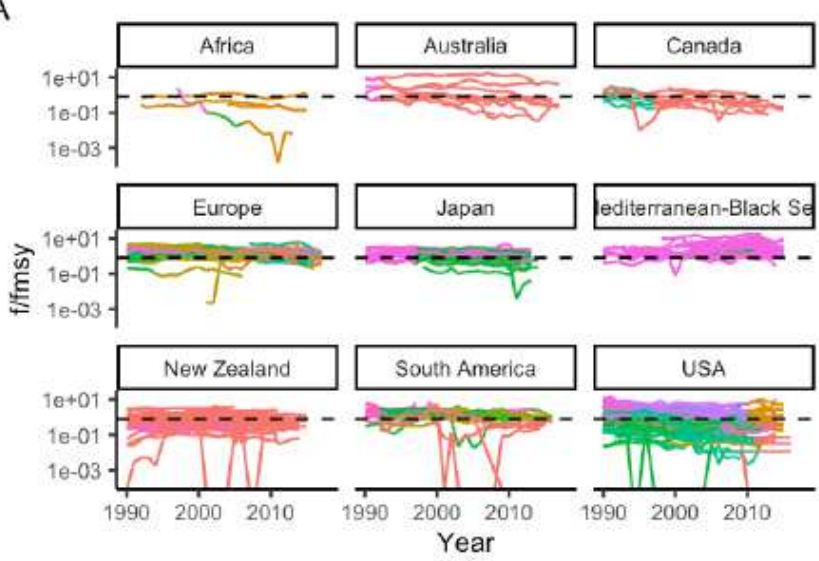

B
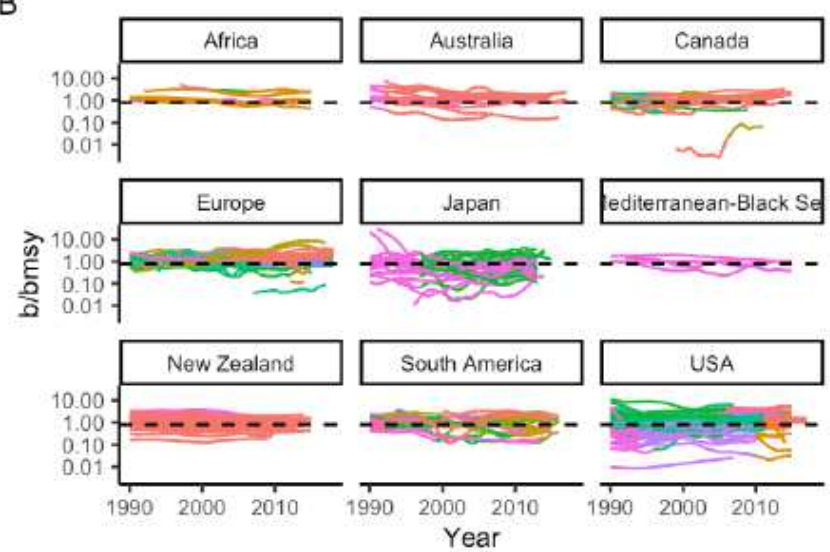

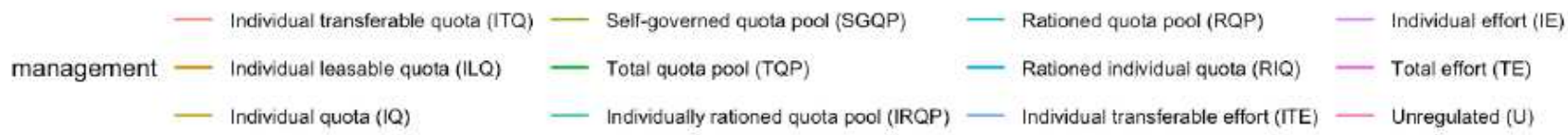

C

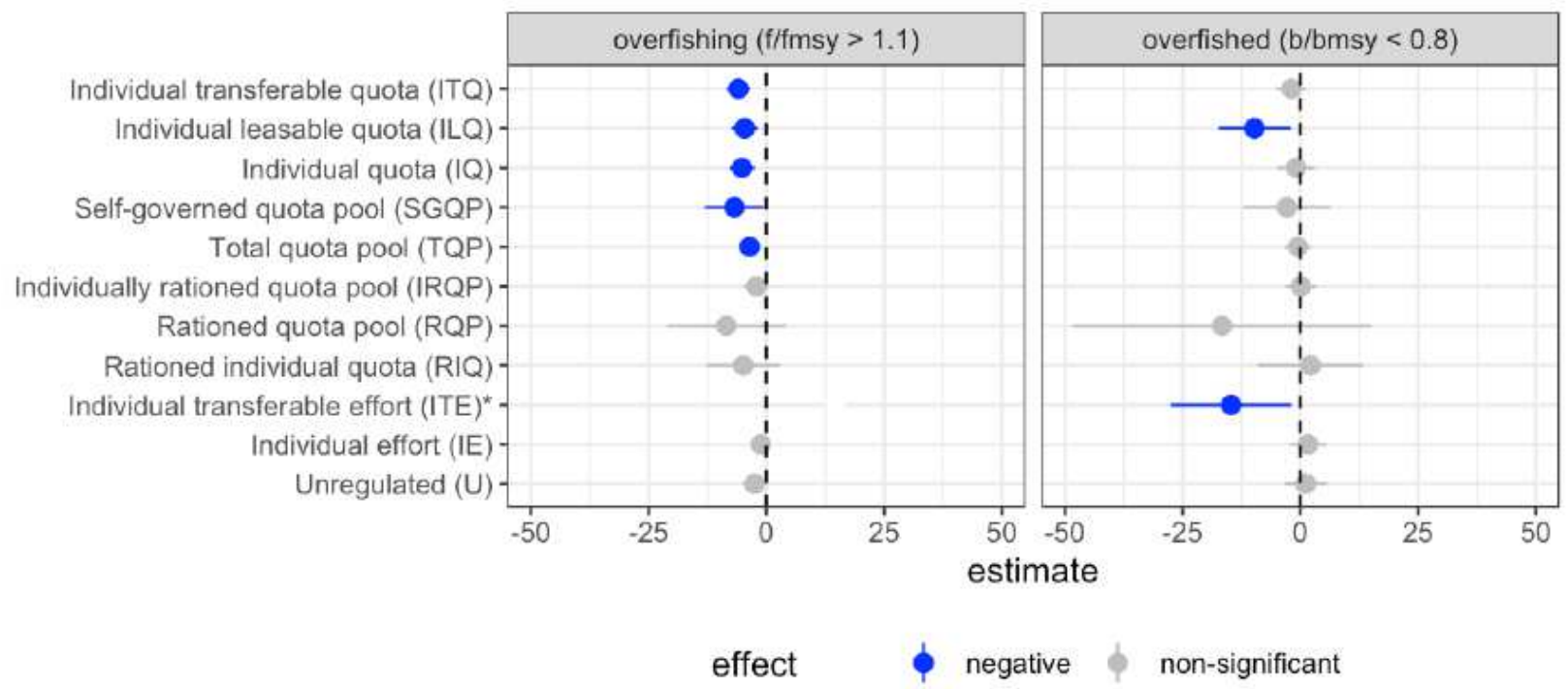

Figure 2

A) F/Fmsy for all classified fisheries management systems (dotted line indicates the threshold for overfishing, i.e., when F/Fmsy = 1.1. B). B/Bmsy for all classified fisheries management systems (dotted line indicates the threshold for overfished, i.e., when B/Bmsy = 0.8). C) Estimates and 95 percent confidence intervals of management systems compared to TE. Negative (blue) values indicate that the management system reduces the probability of the outcome variable, for example IQ reduces the probability of overfishing compared to TE. The non-significant effect for ITE cannot be displayed in the figure due to wide standard errors (Table B1). 
A
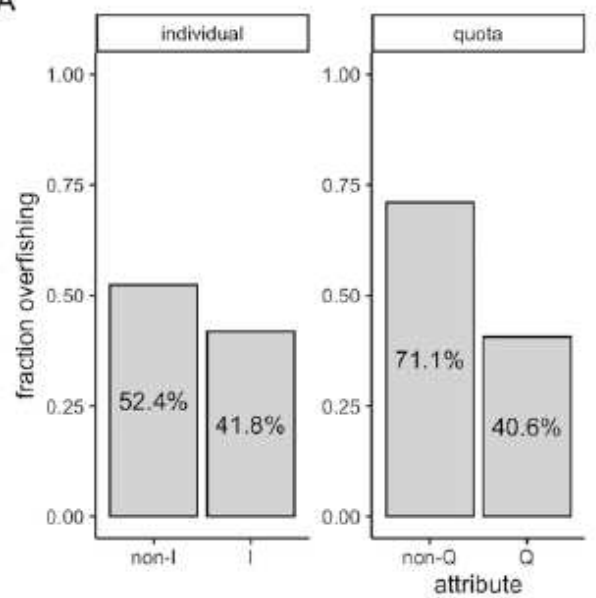

C
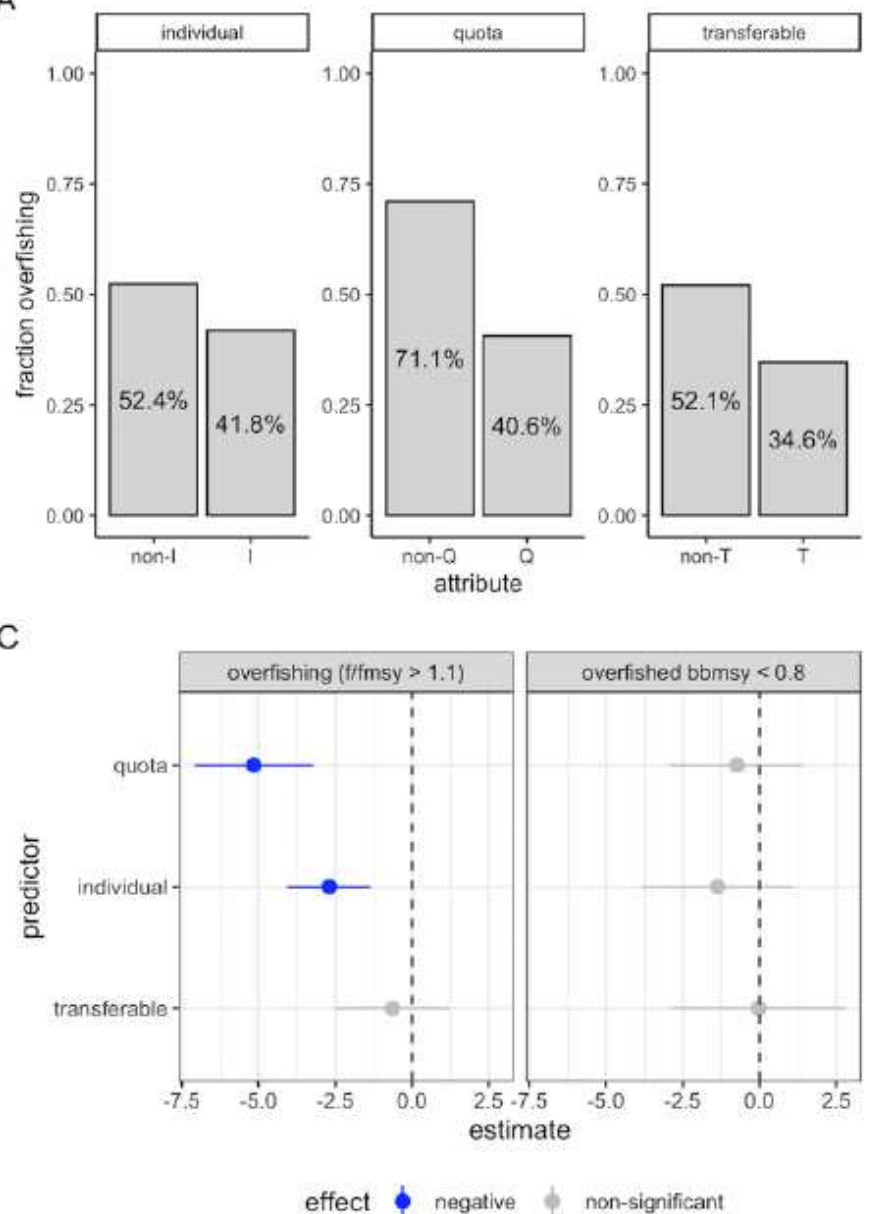

B
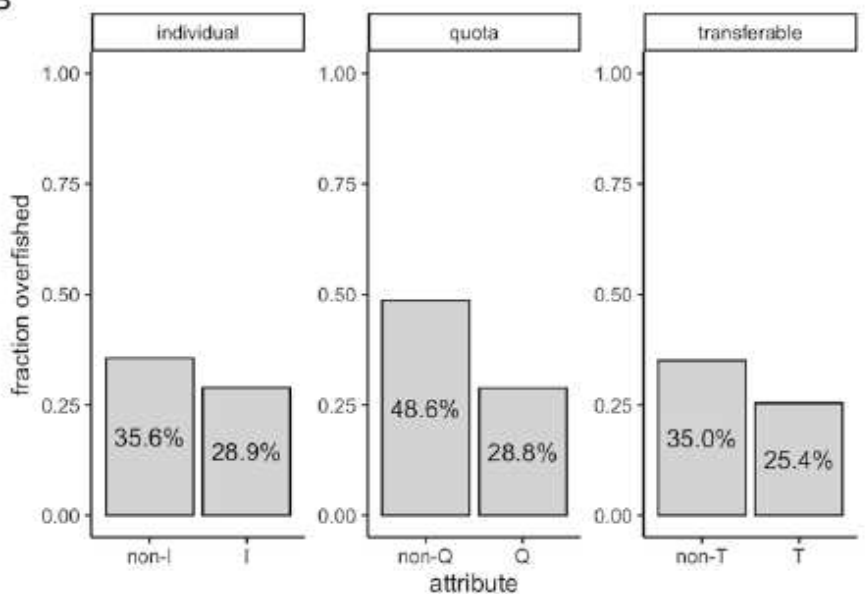

D

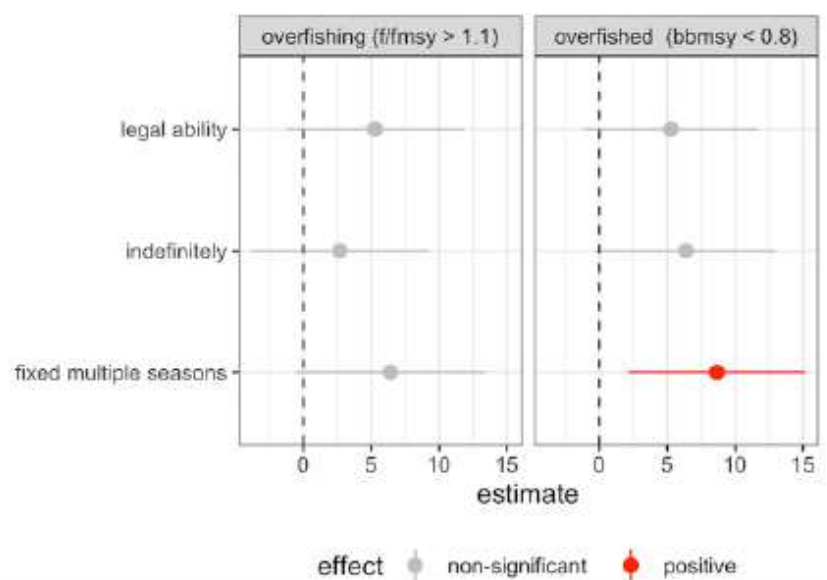

\section{Figure 3}

A) frequency of overfishing ( $/$ /Fmsy $>1.1)$ and $B)$ frequency of overfished observations $(B / B m s y<0.8)$ for the attributes I, T, and Q. Each observation is a stock-year combination. C) Mixed effects results for the attributes I, T, and Q. Negative (blue) effects indicate a reduced probability of overfishing for I and Q (overfishing: 343 stocks with 6803 observations; overfished: 299 stocks with 6875 observations). D) Effects for the duration of fishing opportunities compared to a single season. The positive (red) value indicates an increased probability of the overfished state for fixed multiple seasons. 

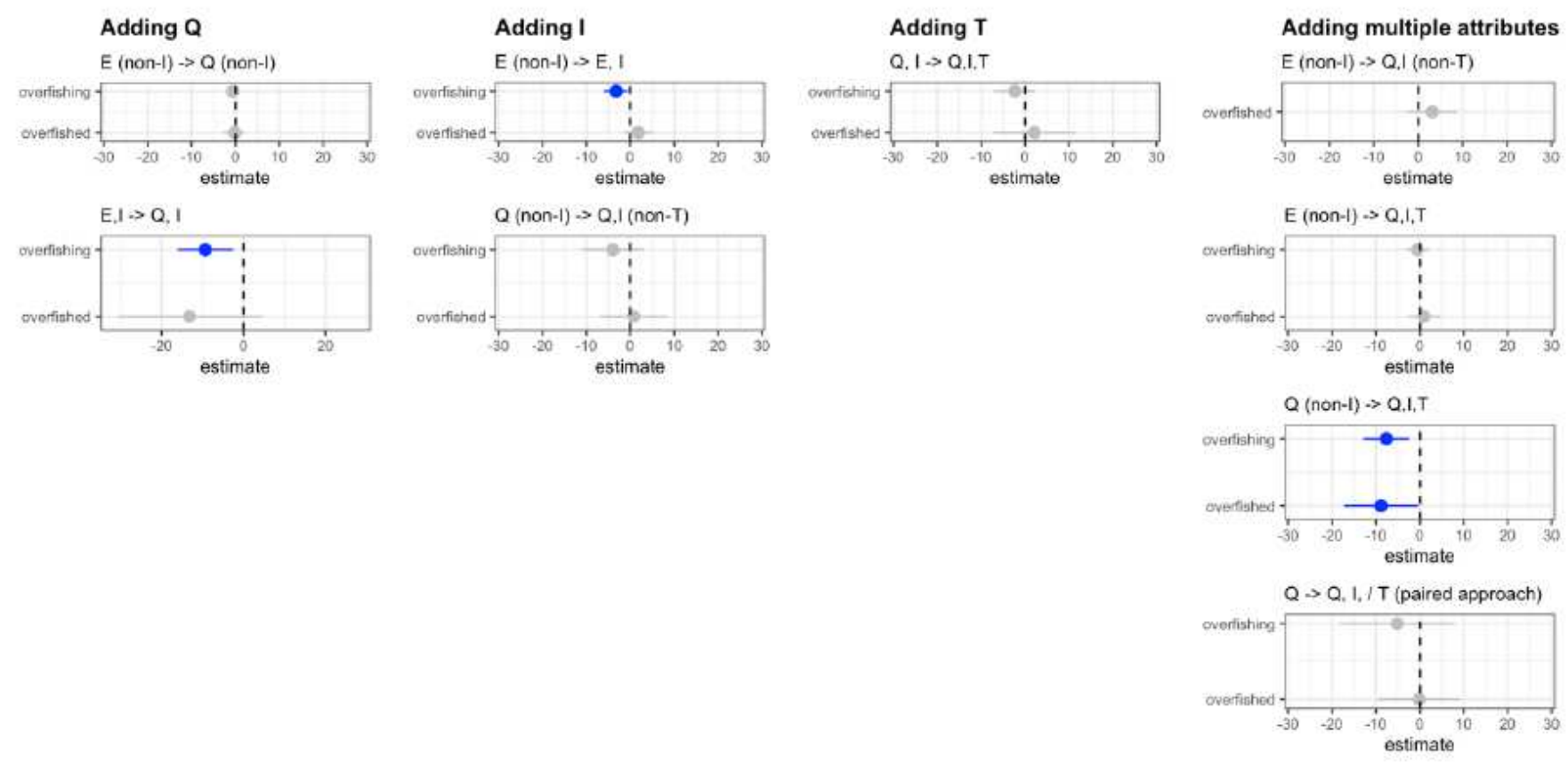

\section{Figure 4}

DiD estimates of treatment effects, outcomes for the probability of overfishing and overfished outcomes. DiD estimates are indicated for the addition of Q (TE systems transitioning to pooled quota systems, IE systems transitioning to individual quota systems), I (TE systems transitioning to IE, pooled quota systems transitioning to individual (non-transferable) quota systems, $T$ (individual quota systems transitioning to ITQ systems), and multiple attributes simultaneously. Negative (blue) values indicate that the attribute reduced the probability of the outcome variable. 